
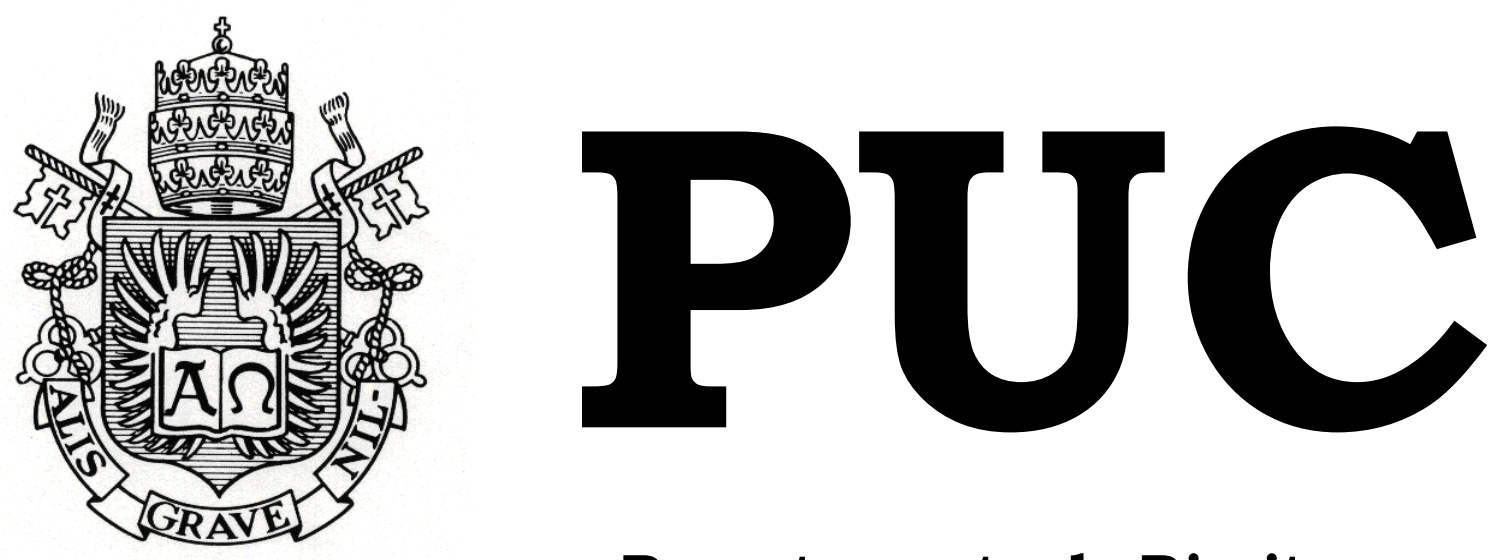

Departamento de Direito

\title{
A TUTELA DAS FAMÍlIAS SIMULTÂNEAS NO ORDENAMENTO JURÍDICO BRASILEIRO
}

Por

IONÁ CYTRYNBAUM SPATZ

ORIENTADOR: BRUNO VAZ

2014.1

PONTIFÍCIA UNIVERSIDADE CATÓLICA DO RIO DE JANEIRO RUA MARQUES DE SÃO VICENTE, 225 - CEP 22453-900

RIO DE JANEIRO - BRASIL 


\title{
A TUTELA DAS FAMÍlIAS SIMULTÂNEAS NO \\ ORDENAMENTO JURÍDICO BRASILEIRO
}

\author{
por \\ IONÁ CYTRYNBAUM SPATZ
}

Monografia apresentada ao Departamento de Direito da Pontificia Universidade Católica do Rio de Janeiro (PUC-Rio) para a obtenção do Título de Bacharel em Direito.

Orientador: Bruno Vaz 
À minha mãe,

Gostaria de dedicar o presente trabalho à minha mãe, que sempre esteve ao meu lado, me ajudando e me dando força em todos os momentos da minha vida. Minha fonte de inspiração e a razão de tudo que fiz, faço e ainda ei de realizar. Obrigada, mãe. Eu te amo. 


\section{AGRADECIMENTOS}

É chegada a conclusão de mais uma etapa da minha vida. Dessa forma, é imperioso fazer alguns agradecimentos a pessoas extremamentes especiais que fizeram parte dessa trajetória.

Primeiramente gostaria de agradecer à minha mãe, por ter me dado educação e me inspirado a ser a pessoa que sou hoje. Sem ela, nada disso seria possível.

Agradeço também a todos os professores com quem eu tive o prazer de aprender ao longo desses anos de graduação. Ensinamentos que levarei para a minha vida, não só profissionais como pessoais.

Agradeço em especial aos professores de Direito de Família e Sucessões, que conseguiram me passar a paixão que lhes move nessa árdua profissão, e, principalmente, ao meu querido orientador, exemplo de professor, Bruno Vaz, pelo carinho, paciência e dedicação ao longo deste percurso.

Gostaria de agradecer também a toda minha família. Família, esta, plural, recomposta, formada por minha mãe, meu pai, meu padrastro e minhas irmãs bilaterais, unilaterias e também a de coração.

Um muito obrigada a todos pela inspiração e contribuição na minha formação pessoal e profissional. 
“(...) Porque a minha vida é a minha vida. A sua vida é a sua vida. Elas quiseram se juntar e andar com as mãos unidas. Simples assim, sem essa de eu te dou a vida. Eu dou o amor, somente, porque ele vale mais que tudo. E com ele a gente aprende a se amar mais e melhor. Porque o amor não tem título, muito menos definição.” 


\section{RESUMO}

O presente trabalho monográfico tem como objetivo analisar a evolução legislativa em matéria de direito de família face aos novos reconhecimentos de vínculos afetivos como entidades familiares. A partir daí, passamos a tratar da marginalização dos relacionamentos afetivos simultâneos, bem como a posição do poder judiciário frente à essas "formas de família”. É uma temática atual, na qual discute-se o princípio da monogamia em contraposição com a realidade social que se impõe na contemporaneidade.

\section{PALAVRAS-CHAVE}

Família. União Estável. Casamento. Concubinato. Famílias Simultâneas. Famílias Paralelas. Poliamor. Princípios Fundamentais. Jurisprudência. 


\section{SUMÁRIO}

1.ENTIDADES FAMILIARES ......................................................... 08

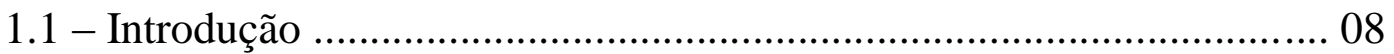

1.2 - A evolução do conceito de família no sistema jurídico brasileiro .... 10

1.3 - Abertura do casamento para união estável ...................................... 12

2. ROMPENDO AS AMARRAS PATRIARCAIS E ARCAICAS ............ 16

2.1 - Conceituando: o concubinato e a união estável ................................. 16

2.2- A Súmula 380 do STF e a sociedade de fato ................................... 18

3. OS PILARES DA FAMÍLIA CONTEMPORÂNEA ........................... 22

3.1 - A minimização do patrimônio e a maximização da afetividade ......... 22

3.2 - $\mathrm{O}$ dever de fidelidade $\mathrm{x}$ lealdade ................................................... 26

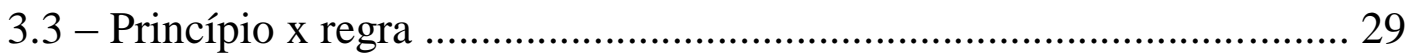

4. AS FAMÍLIAS SIMULTÂNEAS ............................................... 32

4.1 - Conceituando: o poliamor e o paralelismo familiar ........................ 32

4.2 - As famílias paralelas no ordenamento jurídico brasileiro ................ 34

4.3 - As uniõe estáveis paralelas no ordenamento jurídico brasileiro ........ 47

4.4 - A questão previdenciária ........................................................... 52

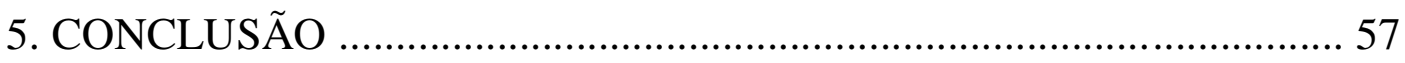

6. BIBLIOGRAFIA ….................................................................... 59 


\section{LISTA DE ABREVIATURAS E SIGLAS}

$\S$ - Parágrafo

AC - Apelação Cível

ART - Artigo

CC - Código Civil

CF - Constituição Federal

N. ${ }^{\circ}$ - Número

P. - Página

STF - Supremo Tribunal Federal

STJ - Supremo Tribunal de Justiça

REL - Relator(a)

Resp - Recurso Especial 


\section{ENTIDADES FAMILIARES}

\section{1 - INTRODUÇÃO}

Considerando os princípios constitucionais do legislador de 1988 e traçando uma linha evolutiva das formas de entidade familiar, a família contemporânea, em contraposição ao conceito antiquado de família - aquele formalizado unicamente através do casamento e com a presença de filhos - é agora plural, isonômica e eudemonística, e não mais singular, hierárquica e transpessoal. Há, portanto, um novo paradigma da conjugalidade, no qual reconhece-se a entidade familiar, apesar da mesma não ser constituída através do casamento.

À medida que a sociedade evolui, transforma-se e rompe com as tradições, surgem novos parâmetros e, então, é necessário fazer uma análise e um controle no intuito de verificar se as leis existentes atendem, de fato, à nova realidade social. Dessa forma, uma legislação desatualizada, defasada e que não atende às novas necessidades, não possui condições de cumprir suas funções primordiais. É preciso, portanto, que a legislação acompanhe tais mudanças, de modo a se enquadrar no novo cenário social.

Com efeito, enquanto o legislador não acompanha a evolução dos usos e costumes, as mudanças de mentalidade e a evolução do conceito de moralidade, ou seja, havendo lacuna da lei, há que se subsidiar na determinação do art. $4^{\circ}$ da Lei de Introdução ao Código Civil, aplicando a analogia, os costumes e os princípios gerais de direito, de modo a acompanhar as mudanças sociais com maior dinamismo.

A mesma realidade impõe, hoje, a discussão a respeito das "Famílias Simultâneas", em que um indivíduo mantém, simultaneamente, relações afetivas com duas ou mais pessoas, na concomitância de um casamento ou união estável. Esse modelo familiar, embora não reconhecido juridicamente 
como um modelo válido de família, vem se tornando cada vez mais comum em nossa sociedade, necessitando urgentemente de uma proteção jurídica.

A família é uma construção cultural e o conceito de família, por sua vez, não é estático. Como adverte Sérgio Gischkow Pereira, “o regramento jurídico da família não pode insistir, em perniciosa teimosia, no obsessivo ignorar das profundas modificações culturais e científicas, petrificado, mumificado e cristalizado em um mundo irreal, ou sofrerá do mal da ineficácia" 1 .

Assim, o objetivo desse trabalho monográfico é trazer uma noção geral do tema, ainda pouco discutido. Partindo dessas premissas, no primeiro capítulo iniciamos através da evolução do conceito de família no sistema jurídico brasileiro e o que hoje se reconhece como entidades familiares.

Já no segundo capítulo, desenvolvemos a evolução do concubinato e da união estável na jurisprudência brasileira, apresentando suas diferenças. Em seguida, no terceiro capítulo, passamos a abordar a supremacia do princípio da afetividade na Direito de Família contemporâneo, travando uma reflexão, inclusive, quanto os deveres de fidelidade e lealdade impostos pelo legislador.

No quarto capítulo, apresentamos as espécies de Famílias Simultâneas, expondo as principais correntes doutrinárias em que se divide o assunto, com a inclusão da análise de diversos julgados dos Tribunais pátrios. Por fim, analisamos como as famílias simultâneas são tratadas na seara previdênciária.

\footnotetext{
${ }^{1}$ PEREIRA, Sérgio Gischkow. Estudos de Direito de Família. $1^{\text {a }}$ edição. Porto Alegre: Livraria do Advogado Editora, 2004. P.35.
} 


\section{2 - A EVOLUÇÃo do CONCEITO DE FAMÍlIA NO SISTEMA JURÍDICO BRASILEIRO}

O conceito de família passou por diversas transformações ao longo do tempo, se moldando às mudanças e fonômenos sociais. Na vigência do Código Civil de 1916 - influênciado pelo modelo de família patriarcal -, apenas as uniões constituídas pelo casamento eram protegidas, e as advindas à margem do matrimônio eram denominadas "concubinato". O casamento era indissolúvel e os vínculos extramatrimoniais, assim como os filhos ilegítimos, ou seja, havidos fora do casamento, eram discriminados e excluídos de quaisquer direitos.

Significativas mudanças sociais e o surgimento de novos paradigmas impuseram alterações legislativas expressivas. $\mathrm{O}$ advento do Estatuto da Mulher Casada (Lei 4.121/62), que devolveu à mulher casada sua plena capacidade civil, bem como a instituição do divórcio (EC 9/77 e Lei 6.515/77), que eliminou a idéia sacralizada da família e do matrimônio, foram pequenas grandes conquistas que abriram espaço para o rompimento definitivo do arcaico conceito de família.

Como bem preceituam Cristiano Chaves de Farias e Nelson Rosenvald:

Com efeito, a família tem o seu quadro evolutivo atrelado ao próprio avanço do homem e da sociedade, mutável de acordo com as novas conquistas da humanidade e descobertas científicas, não sendo crível, nem admissível, que esteja submetida a idéias estáticas, presas a valores pertencentes a um passado distante, nem a suposições incertas de um futuro remoto. É realidade viva, adaptada aos valores vigentes. ${ }^{2}$

A legislação brasileira estava em desconforme com os novos ideais consagrados no pós guerra. Fazia-se necessária uma mudança legislativa

\footnotetext{
${ }^{2}$ FARIAS, Cristiano Chaves de; ROSENVALD, Nelson. Curso de Direito Civil. Famílias. Editora JusPodivam. $4^{\circ}$ edição. 2012. P. 41
} 
radical que culminou com o advento, em 1988, da atual Constituição Federativa Brasileira, que, nas palavras de Zeno Veloso, "num único dispositivo, espancou séculos de hipocrisia e preconceito". ${ }^{3}$ Com base nos ideais franceses de igualdade, liberdade e fraternidade, consagrados posteriormente na Declaração dos Direitos do Homem e do Cidadão ${ }^{4}$, o aspecto patrimonial, antes privilegiado, deu espaço ao aspecto pessoal, colocando a pessoa como centro da tutela jurídica.

No tocante ao direito de família, a Carta Magna instaurou a igualdade entre homem e mulher, reconheceu a união estável como entidade familiar, dando-lhe igual proteção à família constituída pelo casamento, bem como definiu como entidade familiar a "família monoparental". Consagrou, ainda, a igualdade dos filhos, sejam eles adotados, havidos na constância do casamento ou não, além da possibilidade da dissolução matrimonial vir a ocorrer extrajudicialmente (Lei 11.441/07 - art. 1.124-A, CPC) e sem a necessidade da separação, da identificação das causas da dissolução e, principalmente, de prazos (EC 66/10).

\section{Segundo Letícia Ferrarini:}

A família, fundada no casamento, não é mais a única consagrada pelo Direito Constitucional Brasileiro. A Constituição Federal de 1988 harmonizou as normas com os "fatos da vida", definindo como entidade familiar também a comunidade formada por qualquer dos pais e seus descendentes (família monoparental). Da mesma forma, o constituinte reconheceu a união estável como entidade familiar. ${ }^{5}$

Em total descompasso com o novo sistema jurídico de 1988, o projeto do novo Código Civil passou por diversas emendas e inúmeros remendos foram feitos, até entrar em vigor em 2003. Apesar das profundas mudanças

\footnotetext{
${ }^{3}$ VELOSO, Zeno. Homossexualidade e direito. Belém: Jornal O Liberal, 1999. P.3

${ }^{4}$ Artigo $1^{\circ}$ : Todas os seres humanos nascem livres e iguais em dignidade e direitos. São dotados de razão e consciência e devem agir em relação uns aos outros com espírito de fraternidade.

${ }^{5}$ FERRARINI, Letícia. Famílias Simultâneas e seus Efeitos Jurídicos: Pedaços da Realidade em Busca da Dignidade. $1^{\text {a }}$ Edição. Porto Alegre: Livraria Do Advogado Editora, 2010. P. 78.
} 
legislativas, ainda assim, a atual legislação civil encontra-se em defasagem com os fenômenos sociais, necessitando de uma complementação, em sede jurisprudencial. É o caso do recente reconhecimento pelo Supremo Tribunal Federal (STF), que ao julgarem a Ação Direta de Inconstitucionalidade (ADI) 4277 e a Arguição de Descumprimento de Preceito Fundamental (ADPF) 132, reconheceram a união estável para casais do mesmo sexo, estendendo a proteção estatal também para o modelo familiar homoafetivo.

Na lição de Maria Berenice Dias:

É necessário ter uma visão pluralista da família, abrigando os mais diversos arranjos familiares, devendo-se buscar o elemento que permite enlaçar no conceito de entidade familiar todos os relacionamentos que têm como origem em um elo de afetividade, independentemente de sua conformação. O desafio dos dias de hoje é achar o toque identiicador das estruturas interpessoais que autorize nominá-lasc como família. Esse referencial só pode ser identificado no vínculo que une seus integrantes. ${ }^{6}$

A família contemporânea, portanto, funda-se principalmente no afeto e na preservação da dignidade da pessoa humana, possibilitando a formação de novos arranjos familiares pautados no afeto. É a supremacia da dignidade humana, em detrimento aos valores meramente patrimoniais.

\section{3 - ABERTURA DO CASAMENTO PARA UNIÃO ESTÁVEL}

Os efeitos patrimoniais provenientes da - hoje denominada - União Estável foram, paulatinamente, sendo reconhecidos pela jurisprudência, a partir da década de 1960. Em um primeiro momento, os Tribunais passaram a conceder alimentos à concubina de forma oculta, sob o pretexto de que

\footnotetext{
${ }^{6}$ DIAS, Maria Berenice. Manual de Direito das Famílias. $8^{\mathrm{a}}$ edição. Editora revista dos Tribunais. 2011. São Paulo. P. 43
} 
seria "indenização por serviços domésticos prestados", através do fundamento da inadimissibilidade do enriquecimento sem causa, nos casos em que a mulher era dependente financeiramente, ou seja, não exercia atividade remunerada e não tinha outra fonte de renda.

Em decorrência de queixas generalizadas, em 1964, através da Súmula $380^{8}$, o STF, passou a tratar as uniões extramatrimoniais como sociedades de fato. Entretanto, para ensejar a divisão dos bens adquiridos na constância da relação, havia a necessidade de prova da contribuição financeira efetiva para a constituição do patrimônio comum. Nesse mesmo ano, o STF também editou a Súmula $382^{9}$, entendendo não haver necessidade do casal residir sob o mesmo teto para a caracterização do concubinato.

Dessa forma, lentamente os direitos dos companheiros foram sendo reconhecidos pelos Tribunais, até o seu efetivo reconhecimento através da promulgação da Constituição Federal de 1988. Sustenta Paulo Lôbo que o caput do art. 226 da $\mathrm{CF}^{10}$ é cláusula geral de inclusão, não sendo admissível excluir qualquer entidade que preencha os requisitos de afetividade, estabilidade e ostensibilidade ${ }^{11}$.

Nesse passo, em 1994, foi editada a Lei 8.971/94 cujo objetivo era regular o direito dos companheiros em relação à alimentos e à sucessão. Embora sem definir um conceito exato para a configuração da união estável, o art. $1^{\circ}$ da referida lei determinou alguns pressupostos obrigatórios

\footnotetext{
${ }^{7}$ INDENIZAÇÃO POR SERVIÇOS PRESTADOS. CONCOMITÂNCIA DE RELACIONAMENTOS. Já afastada a existência de união estável quando do julgamento da demanda alimentar, em razão do vínculo conjugal paralelo mantido pelo varão, outra alternativa não há senão a de ressuscitar o instituto da indenização por serviços prestados, a fim de evitar a flagrante injustiça de deixar desamparada a mulher que se dedicou exclusivamente ao companheiro durante 19 anos de sua vida. Por maioria, negado provimento ao apelo de H. F. C. e provido em parte o apelo de E. T. G. (Apelação Cível No 70016516932, Sétima Câmara Cível, Tribunal de Justiça do RS, Relator: Maria Berenice Dias, Julgado em 08/11/2006)

${ }^{8}$ Súmula 380, STF: "Comprovada a existência de sociedade de fato entre os concubinos, é cabível a sua dissolução judicial, com a partilha do patrimônio adquirido pelo esforço comum"

9 Súmula 382, STF: "a vida em comum sob o mesmo teto, more uxorio, não é indispensável à caracterização do concubinato"

${ }^{10}$ Art. 226.: A família, base da sociedade, tem especial proteção do Estado.

${ }^{11}$ LÔBO, Paulo Luiz Netto. Entidades familiares constitucionalizadas: para além do numerus clausus. Anais do III Congresso Brasileiro de Direito de Família. Belo Horizonte, 2002. P.95
} 
para a caracterização desse modelo familiar: fixou prazo de convivência de cinco anos ou a existência de prole comum. Contudo, tal estatuto legal não reconheceu a união estável entre pessoas separadas de fato, o que foi alvo de inúmeras críticas. No plano da sucessão, incluiu o companheiro sobrevivente como herdeiro legítimo, no caso de inexistirem descendentes ou ascendentes, e assegurou o usufruto sobre parte dos bens deixados pelo de cujus.

Logo após, em 1996, foi editada a Lei 9.278/96, que veio regular o $\S 3^{\circ}$ do art. 226 da Constituição Federal. Tal lei acabou por revogar em parte a Lei 8.971/94, uma vez que desconsiderou os pressupostos por ela determinados. Dispensou o requisito da existência de prole comum, e ao não quantificar prazo de convivência para o reconhecimento da união estável, suprimiu o prazo de cinco anos estabelecido anteriormente. Além disso, esta lei incluiu os separados de fato para o reconhecimento da união estável, reconheceu, ainda, o direito real de habitação do companheiro e fixou a competência das Varas de Família para o julgamento de litígios, assegurando o segredo de justiça para toda a matéria relativa à união estável. Outrossim, gerou a presunção legal de que os bens adquiridos à título oneroso na constância da união são fruto do esforço comum do casal, não importando a efetiva participação de cada parceiro quando da partilha dos bens.

Contudo, em 2003, com o advento do novo Código Civil, as leis supracitadas (L. 8.971/94 e L. 9.278/96) restaram derrogadas, haja vista que aquele disciplinou a integralidade das matérias nelas previstas. Ademais, o legislador civil entendeu por definir como "companheiros" os casais que vivem em união estável. ${ }^{12}$

\footnotetext{
${ }^{12}$ DAL COL, Helder Martinez. A união estável perante o novo código Civil. IN: CAHALI, Yussef Said; CAHALI, Francisco José (Coord.). Edições especias, 100 anos, Doutrinas Essenciais: Família e Sucessões, vol. II, Entidades Familiares. Revista dos Tribunais, 2011. P. 1077.
} 
Nos ensina Maria Berenice Dias, que tanto o casamento, quanto a união estável são estruturas de convívio que têm origem em elo afetivo. Divergem apenas quanto ao modo de constituição. Nas suas palavras:

\begin{abstract}
Enquanto o casamento tem seu início marcado pela celebração do matrimônio, a união estável não tem termo inicial estabelecido. Nasce da consolidação do vínculo de convivência, do comprometimento mútuo, do entrelaçamento de vidas e do embaralhar de patrimônios. ${ }^{13}$
\end{abstract}

O Código Civil, em seu artigo 1.723, elenca as características da união estável: convivência pública (leia-se notória), contínua, duradoura e estabelecida com o objetivo de constituição de família. Quanto aos impedimentos, o referido diploma legal regulou a união estável à imagem e semelhança do casamento, nos artigos 1.723 e seguintes. Apesar de reconhecida a união estável como entidade familiar, esta ainda não define um estado civil, gerando insegurança jurídica e prejuízos à terceiros.

No tocante aos direitos e deveres, há algumas diferenças do casamento para a união estável. Aos companheiros são estabelecidos deveres de lealdade, respeito e assistência, elencados no art. 1.724, CC, enquanto no casamento os deveres são de fidelidade recíproca, vida no domicílio conjugal e mútua assistência, estes elencados no art. 1.566, CC. Em comum há a obrigação de guarda, sustento e educação dos filhos. Contudo, o descumprimento dos deveres impostos pela lei não gera efeito nenhum: nem impede o reconhecimento da união estável nem impõe sua dissolução.

Quanto aos efeitos patrimoniais, a união estável muito se assemelha ao casamento. No silêncio, o regime legal de ambos é o da comunhão parcial de bens (CC 1.658 a 1.666), ou seja, há uma presunção de colaboração mútua para a formação do patrimônio comum. A forma de

\footnotetext{
${ }^{13}$ DIAS, Maria Berenice. Manual de Direito das Famílias. $8^{a}$ edição. Editora revista dos Tribunais. 2011. São Paulo. P. 171.
} 
optar por outro regime legal no casamento e na união estável, é o pacto antenupcial e o contrato de convivência, respectivamente.

Finalmente, no que tange a conversão da união estável em casamento, a Constituição recomenda a facilitação desta, conforme o $\S 3^{\circ}$ do art. 226, $\mathrm{CF}^{14}$. Tal conversão é vantajosa, pois garante aos companheiros a retroatividade dos efeitos advindos do relacionamento amoroso, desde o início da união estável e não somente a partir da data da conversão.

\section{ROMPENDO AS AMARRAS PATRIARCAIS E ARCAICAS}

\section{1 - CONCEITUANDO: O CONCUBINATO E A UNIÃO ESTÁVEL}

A palavra concubinato carrega consigo o estigma do preconceito, pois, historicamente, o concubinato era tido como uma relação escusa e pecaminosa. Adahyl Lourenço Dias, assim define o concubinato: "ter concubina é possuí-la em more uxório, em coabitação, e manter é sustentála, ao largo do lar conjugal, embora morando com a esposa, porém mantendo-se-lhe à distância: "teúda e manteúda"."15 Antes do advento do novo Código Civil, que só entrou em vigor em 2003, o concubinato era classificado pelos doutrinadores como puro ou impuro.

$\mathrm{O}$ concubinato puro se referia às relações extraconjugais, embora nenhum dos concubinos houvesse algum impedimento para o matrimônio. Tais uniões concebidas fora do casamento eram considerados ilegítimas e refutadas pela sociedade, e, somente passaram a ter algum respaldo legal, em 1988, através da promulgação da Constituição Federal, em que legitimou-se tais relacionamentos, reconhecendo como entidade familiar e denomindo de união estável. Já o denominado concubinato impuro, é a

\footnotetext{
${ }^{14} \S 3^{\circ}$ - Para efeito da proteção do Estado, é reconhecida a união estável entre o homem e a mulher como entidade familiar, devendo a lei facilitar sua conversão em casamento.

${ }^{15}$ DIAS, Adahyl Lourenço. A concubina e o direito brasileiro. $2^{\mathrm{a}}$ edição. São Paulo: saraiva, 1975. P. 42.
} 
relação adúltera, na qual ao menos um tem impedimento para contrair matrimônio, por já estar casado ou viver em união estável com outrem.

Embora já reconhecida a união estável, o termo "concubinato puro" continuou sendo utilizado para diferenciar tais relações daquelas adúlteras. Objetivando retirar da união estável o estigma do preconceito, o legislador do Código Civil de 2002, optou por dar uma definição legal ao concubinato, determinando que "as relações não eventuais entre o homem e a mulher, impedidos de casar, constituem concubinato" (CC, 1.727).

Destarte, o novo Código Civil, suprimiu a classificação de concubinato em puro ou impuro. Isto é, em se tratando de uma relação adultera, tratar-se-á somente de concubinato, sem qualquer qualificativo.

Conforme preleciona Sílvio Venosa: "(...) é importante reiterar que o legislador do Código Civil optou por distinguir claramente o que se entende por união estável e por concubinato, não podendo mais essas expressões serem utilizadas como sinônimas, como no passado" ${ }^{16}$.

Assim, conclui Zeno Veloso: "(...) a união estável é uma relação afetiva qualificada, espiritualizada, aberta, franca, exposta, assumida, constitutiva de família; o concubinato, em regra, é clandestino, velado, desleal, impuro" ${ }^{17}$.

Apesar do legislador ter se preocupado em dar uma formatação ao concubinato, não cuidou, porém, de dar tratamento jurídico aos efeitos dele decorrentes. É essa a crítica que Maria Berenice Dias faz:

Ademais, criar uma figura e nada dizer sobre ela revela postura meramente punitiva. Se um do par deixa de cumprir o dever de fidelidade e mantém duplo vínculo familiar, afronta o consagrado sistema da monogamia. Logo, é injustificável que quem assim aja seja beneficiado. Ao vetar a lei possibilidade de reconhecimento, está suprimindo os efeitos patrimoniais do vínculo que, com ou sem respaldo social, existiu. Isso só

\footnotetext{
${ }^{16}$ VENOSA, Sílvio de Salvo. Direito Civil. Direito de Família. $7^{\text {a }}$ ed. São Paulo: Atlas, 2007. p. 387.

${ }^{17}$ VELOSO, Zeno. Código Civil Comentado. Vol. XVII. Coord. Álvaro Villaça Azevedo. São Paulo: Atlas, 2003. p. 155.
} 
beneficiará o parceiro adúltero, que não irá dividir o patrimônio. ${ }^{18}$

Assim sendo, cabe ao Poder Judiciário proferir decisões a fim de regulador tal figura jurídica, que embora incômoda, é uma realidade, cuja existência não pode ser ignorada. ${ }^{19}$

\section{2- A SÚMULA 380 DO STF E A SOCIEDADE DE FATO}

À época em que as relações afetivas havidas fora do casamento eram tidas como ilegítimas e não eram juridicamente reconhecidas, o STF, exergando a existência de tais relacionamentos e visando evitar o enriquecimento ilícito do varão, editou, em 1964, a Súmula 380, com a seguinte redação: "Comprovada a existência de sociedade de fato entre os concubinos, é cabível a sua dissolução judicial, com a partilha do patrimônio adquirido pelo esforço comum".

Através dessa Súmula, as uniões extramatrimoniais passaram a ser tratadas como sociedades de fato. Entretanto, equiparadas às sociedades de fato, seus integrantes seriam, portanto, sócios. Dessa forma, para ensejar a divisão dos bens adquiridos na constância da relação, havia a necessidade de prova da contribuição financeira efetiva para a constituição do patrimônio comum.

Com o reconhecendo das uniões estáveis na Constituição de 1988, a Súmula perdeu sua aplicabilidade. Apesar disso, ela continuou sendo invocada, até que, em 1996, a lei 9.278/96, estipulou que presumirá ser de

\footnotetext{
18 DIAS, Maria Berenice, A união estável. Disponível em: $<$ http://www.mariaberenice.com.br/uploads/3_-_a_uni\%E3o_est\%E1vel.pdf $>\quad$ Acesso em 23.03.14.

${ }^{19}$ DAL COL, Helder Martinez. A união estável perante o novo código Civil. IN: CAHALI, Yussef Said; CAHALI, Francisco José (Coord.). Edições especias, 100 anos, Doutrinas Essenciais: Família e Sucessões, vol. II, Entidades Familiares. Revista dos Tribunais, 2011. P. 1077.
} 
esforço e colaboração comum o patrimônio adquirido na constância da união ${ }^{20}$.

Contudo, tal súmula ainda vigora e, mais que isso, continua sendo fortemente invocada ${ }^{21}$. No entanto, vale-se dela a fim de impedir o enriquecimento injustificado nos casos de concubinato, ou seja, de famílias paralelas, estas ainda não reconhecidas juridicamente. Apesar da grande evolução legislativa em matéria de direito de família, o legislador ainda possui forte resistência em regular as relações adulterinas ou concubinárias. Embora moralmente refutada pela sociedade, que possui como base a monogamia, essa é uma relação bastante comum e a falta de regulamentação gera uma série de injustiças.

Levando em consideração tal situação fática e jurídica e, visando minimizar - e não eliminar - as injustiças, a jurisprudência dominante e parte da doutrina vêm entendendo o concubinato como uma sociedade de fato, em conformidade com a súmula 380 do STF. Vejamos:

\begin{abstract}
UNIÃO ESTÁVEL RELACIONAMENTO PARALELO A OUTRO JUDICIALMENTE RECONHECIDO. SOCIEDADE DE FATO. A união estável é entidade familiar e o nosso ordenamento jurídico sujeita-se ao princípio da monogamia, não sendo possível juridicamente reconhecer uniões estáveis paralelas, até por que a própria recorrente reconheceu em outra ação que o varão mantinha com outra mulher uma união estável, que foi judicialmente declarada. Diante disso, o seu relacionamento com o de cujus teve um cunho meramente concubinário, capaz de agasalhar uma sociedade de fato, protegida pela Súmula n 380 do STF. Essa questão patrimonial esvaziou-se em razão do acordo entabulado entre a autora e a sucessão. Recurso desprovido, por maioria. ${ }^{22}$
\end{abstract}

\footnotetext{
${ }^{20}$ Lei 9.278/96, art. $5^{\circ}$ - Os bens móveis e imóveis adquiridos por um ou por ambos os conviventes, na constância da união estável e a título oneroso, são considerados fruto do trabalho e da colaboração comum, passando a pertencer a ambos, em condomínio e em partes iguais, salvo estipulação contrária em contrato escrito.

$\S 1^{\circ}$ Cessa a presunção do caput deste artigo se a aquisição patrimonial ocorrer com o produto de bens adquiridos anteriormente ao início da união.

$\S 2^{\circ}$ A administração do patrimônio comum dos conviventes compete a ambos, salvo estipulação contrária em contrato escrito.

${ }^{21}$ Informativo n ${ }^{\circ}$ 0441; Período: 28 de junho a 6 de agosto de 2010; Terceira Turma. Informativo n ${ }^{\circ}$ 0435; Período: 17 a 21 de maio de 2010; Terceira Turma.

${ }^{22}$ Apelação Cível N ${ }^{\circ}$ 70001494236, Sétima Câmara Cível, Tribunal de Justiça do RS, Relator: Sérgio Fernando de Vasconcellos Chaves, Julgado em 20/12/2000.
} 
AGRAVO REGIMENTAL. AGRAVO DE INSTRUMENTO. SOCIEDADE DE FATO.CONCUBINATO IMPURO. REEXAME DO CONJUNTO FÁTICO-PROBATÓRIO DOS AUTOS.IMPOSSIBILIDADE. SÚMULA 7/STJ.

1. A revisão do acórdão recorrido que, ao dirimir a controvérsia, reconhece a caracterização de longa união estável e o consequente direito à partilha dos bens angariados com o esforço comum, demanda imprescindível revolvimento do acervo fático-probatório constante dos autos, providência vedada em sede especial, ut súmula 07/STJ.

2. Não destoa o v. acórdão recorrido da orientação emanada desta Corte acerca da possibilidade de dissolução de sociedade de fato, ainda que um dos concubinos seja casado, visto que o denominado concubinato impuro não constitui circunstância impeditiva da aplicabilidade da súmula 380 do Supremo Tribunal Federal.

3. Agravo regimental desprovido. ${ }^{23}$

Desse modo, os conflitos decorrentes desse tipo de relacionamento são tratados à luz do direito obrigacional e não do direito de família. Os concubinos são figurados como sócios e o relacionamento se transforma em um fictício empreendimento lucrativo, do qual deve-se partilhar os resultados.

Lastimavelmente, assim se posiciona grande parte da doutrina:

Dissolvida a sociedade de fato, o patrimônio comum deverá ser partilhado entre os sócios (art. 1.218, inc. VII, CPC). É totalmente irrelevante ou descabido indagar se os sócios eram ou não concubinos, se um dos sócios ou sócios são pessoas casadas, se durou muito ou pouco o concubinato... A existência ou inexistência da sociedade é assunto que respeita só ao direito das obrigações. ${ }^{24}$

$* * *$

Aos casados, portanto, e que mantém em vigor a coabitação marital, é possível uma união paralela e concomitante com terceira pessoa. O que importa é o fato da mancebia. Existindo a

\footnotetext{
${ }^{23}$ AgRg no Ag 746.042/SP, Quarta Turma, Rel. Min. FERNANDO GONÇALVES, DJ de 17.9.2007.

${ }^{24}$ PORTO, Mário Moacyr . O concubinato e as súmulas no 35 e 380 do STF. Porto Alegre:

AJUIRS, Revista da Associação dos Juízes do RGS, 1984, P. 130 e 131.
} 
mesma, admite-se a dissolução, com todas as consequências decorrentes. Basta a comprovação de alguns elementos exigidos para a caracterização da sociedade de fato, sendo o principal a concorrência na aquisição de bens comuns. ${ }^{25}$

Ainda assim, a simples leitura do dispositivo legal (CC 981) não enseja qualquer analogia entre sociedade de fato e sociedade de afeto. In verbis: "Celebram contrato de sociedade as pessoas que reciprocamente se obrigam a contribuir, com bens ou serviços, para o exercício de atividade econômica e a partilha, entre si, dos resultados."

Maria Berenice Dias critica tal entendimento:

Mais do que uma sociedade de fato, trata-se de uma sociedade de afeto, o mesmo liame que enlaça os parceiros heterossexuais. $\mathrm{Na}$ lacuna da lei, ou seja, na falta de normatização, há que se subsidiar do art. $4^{\circ}$ da Lei de Introdução ao CC, que determina a aplicação da analogia, costumes e princípios gerais de direito. Não se pode fugir de estabelecer analogia com as demais relações que têm o afeto por causa, ou seja, o casamento e as uniões estáveis. Não se podem confundir as questões jurídicas com as questões morais e religiosas. ${ }^{26}$

Isto posto, a concubina ainda não tem direito a alimentos, direitos sucessórios ou direito à meação, pois tal relação não é reconhecida como entidade familiar, mas tão somente como uma sociedade de fato, sendo tratada tão somente à luz do direito obrigacional.

Dessa forma, a competência para apreciar as questões envolvendo união estável é da Vara de Família, e a ação correspondente é ação de reconhecimento e dissolução de união estável. Por sua vez, a competência para apreciar questões envolvendo o concubinato é da Vara Cível, e a ação correspondente é denominada ação de reconhecimento e dissolução de sociedade de fato. Reconhecida, portanto, a existência de uma sociedade de fato, pelo juízo das Varas Cíveis, é determinada a partilha do patrimônio

\footnotetext{
${ }^{25}$ RIZZARDO, Arnaldo. Direito de Família. $2^{\mathrm{a}}$ edição. Editora forense, 2004. P. 913.

26 DIAS, Maria Berenice. União Homossexual: aspectos jurídicos. Disponível em: 〈http://www.gontijo-familia.adv.br/2008/artigos_pdf/Maria_berenice/Uniaohomo.pdf> Acesso em: 03 abr. 2009.
} 
comum, mediante a efetiva prova de sua colaboração na formação do mesmo.

\section{OS PILARES DA FAMÍLIA CONTEMPORÂNEA}

\section{1 - A MINIMIZAÇÃO DO PATRIMÔNIO E MAXIMIZAÇÃO DA AFETIVIDADE}

A flexibilização das relações interpessoais, decorrente do progressivo rompimento do conceito sacralizado de família matrimonializada, tem conduzido a sociedade à aceitação das mais variadas formas de relacionamento, sejam elas positivadas ou não. ${ }^{27}$ Já dizia Eça de Queiros, indo muito à frente de seu tempo, "o amor paira acima das convenções sociais". Dessa forma, rompendo com as convenções sociais da época, a sociedade evoluiu e o conceito de família ampliou-se, albergando formas de relacionamento que se estruturam a partir de um comprometimento amoroso, sem a necessidade do selo matrimonial.

Entendendo que o afeto é o elemento implusionador na fundação da família, explicita Louzada:

[...] o conceito de família restou flexibilizado, indicando que seu elemento formador precípuo é, antes mesmo do que qualquer fator genético, o afeto. Hoje o afeto dá os contornos do que seja uma família. Se tivermos em mente que é o afeto o elemento fundante da família, e que a Constituição Federal nos trouxe um rol exemplificativo de núcleos familiares, forçoso admitir que duas pessoas do memso sexo, unidas pelo afeto, formam uma família. Os tipo de entidades familiares explicitados nos parágrafos do art. 226 da Constituição são meramente exemplificativos, sem embargo de serem os mais comuns, por isso mesmo merecendo referência expressa. As demais entidades familiares sao tipos implícitos incluídos no âmbito de abrangência do conceito amplo e indeterminado de

27 DIAS, Maria Berenice. Adultério, bigamia e união estável: realidade e responsabilidade. Disponível em: <http://www.mariaberenice.com.br/uploads/4_adult\%E9rio\%2C_bigamia_e_uni\%E3o_est\%E1v el_-_realidade_e_responsabilidade.pdf > Acesso em 23.03.14. 
família, indicado no caput. Como todo conceito indeterminado, depende de concretização dos tipos, na experiência da vida, conduzindo à tipicidade aberta, dotada de ductibilidade e adaptabilidade. $^{28}$

A antiga primazia dos interesses patrimonias deu espaço para a valorização do afeto como elemento norteador para formação de entidades familiares. Assim, o afeto passou a ter valor jurídico na esfera das relações familiares, sendo instrumentalizado através do princípio da dignidade da pessoa humana. Com efeito, a família contemporânea está pautada, principalmente, no afeto entre seus entes. Assim, diante da crescente evolução nas relações familiares e do declínio do arcáico modelo patriarcal, matrimonializado e patrimonialista, temos hoje um modelo de família eudemonista, fundado no afeto entre seus membros.

Assim, esclarece Paulo Lôbo:

A concepção revolucionária da família como lugar de realização dos afetos, na sociedade laica, difere da que a tinha como instituição natural e de direito divino, portanto imutável e indissolúvel, na qual o afeto era secundário. A força da afetividade reside exatamente nessa aparente fragilidade, pois é o unico elo que mantém pessoas unidas nas relações familiares. ${ }^{29}$

Desta forma, a família tradicional pautada pelo direito patrimonial está em extinção, uma vez que a família contemporânea é fundada na solidariedade, na diginidade da pessoa humana e na cooperação entre seus membros, que se obrigam mutuamente em uma comunhão de vida. Nessa perspectiva, a família eudemonista é fruto dos laços afetivos e da solidariedade mútua entre os conviventes, e não por simples vínculos institucionais e jurídicos.

\footnotetext{
${ }^{28}$ LOUZADA, Ana Maria Gonçalves. Evolução do conceito de família. 2012. Disponível em: <http://www.amagis.org.br/index.php?option=com_content\&view=article\&id=191\%3Aevolucaodo-conceito-de-familia-juiza-ana-maria-goncalves-louzada\&catid=11\&Itemid=30> Acesso em 20.03.14.

${ }^{29}$ LÔBO, Paulo. Direito Civil. Famílias. São Paulo. Editora Saraiva. 2008. P.52.
} 
Surge, portanto, uma nova forma de se pensar o conceito de família. Nas palavras de Maria Berenice Dias: "Surgiu um novo nome para essa nova tendência de identificar a família pelo seu envolvimento afetivo: família eudemonista, que busca a felicidade individual vivendo processo de emancipação de seus membros" ${ }^{30}$. Ainda para a referida autora:

O eudemonismo é a doutrina que enfatiza o sentido de busca pelo sujeito de sua felicidade. A absorção do principio eudemonista pelo ordenamento altera o sentido da proteção jurídica da família, deslocando-o da instituição para o sujeito ${ }^{31}$.

Desde os tempos mais primórdios, é através do afeto que se constroem as relações interpessoais formadoras da família, motivo pelo qual merece maior atenção da área jurídica. Embora não seja um princípio explícito, nas palavras de Lôbo, o princípio da afetividade "é o princípio que fundamenta o direito de família na estabilidade das relações socioafetivas e na comunhão de vida, com primazia sobre as considerações de caráter patrimonial ou biológico". 32

Neste sentido, preceituam José Lamartine Correa de Oliveira e Francisco José Ferreira Muniz:

A família transforma-se no sentido de que se acentuam as relações de sentimentos entre os membros do grupo: valorizamse as funções afetivas da família, que se torna o refúgio privilegiado das pessoas contra a agitação da vida nas grandes cidades e das pressões econômicas e sociais. É o fenômeno social da família conjugal, ou nuclear ou de procriação, onde o que mais conta, portanto, é a intensidade das relações pessoais de seus membros. ${ }^{33}$

Diante desta nova concepção, Paulo Lôbo elucida:

\footnotetext{
${ }^{30}$ DIAS, Maria Berenice. Manual de Direito das Famílias. $8^{\text {a }}$ edição. Editora revista dos Tribunais. 2011. São Paulo. P. 52.

${ }^{31}$ Idem, p. 52-53.

${ }^{32}$ LÔBO, Paulo. Direito Civil. Famílias. São Paulo. Editora Saraiva. 2008. P.47.

${ }^{33}$ OLIVEIRA, José Lamartine Correa de; MUNIZ, Francisco José Ferreira. Curso de direito de família. $4^{\mathrm{a}}$ ed. Curitiba: Juruá, 2002. p. 13.
} 
A família atual está matrizada em paradigma que explica sua função atual: a afetividade. Assim, enquanto houver affectio haverá família, unida por laços de liberdade e responsabilidade, e desde que consolidada na simetria, na colaboração, na comunhão de vida. ${ }^{34}$

Nesta mesma linha, preceitua Rolf Madaleno que "o Direito de Família não mais se restringe aos valores destacados de ser e ter, porque ao menos entre nós, desde o advento da Carta Política de 1988 prevalece a busca e o direito pela conquista da felicidade a partir da afetividade.,"35

Entendendo que o amor é o elemento constitutivo de entidades familiares, Maria Berenice Dias defende o reconhecimento de todas as formas de relacionamentos que se formam a partir do comprometimento amoroso e da comunhão de vidas:

Por mais que se tente, não há expressão mais adequada para definir quem ama e quem é amado do que a palavra amante. No latim, amante, particípio presente do verbo amar, significa aquele que ama. Se duas pessoas estão juntas exclusivamente em razão do amor que as une, aquela que ama é amante, como também é amante quem é amado. $\mathrm{O}$ fato de os amores, outrora estigmatizados pela clandestinidade, haverem se apropriado desse termo não pode implicar que esse belo vocábulo fique relegado para sempre ou condenado ao esquecimento. Ao contrário, seu real sentido deve ser o bastante para revivificá-lo em uma nova dimensão, que não é outra senão a sua acepção nativa: amantes são aqueles se amam.

Amante serve, pois, tanto para denominar os partícipes de uma união estável, como para a identificação da nova entidade familiar. Ao constituírem essa espécie de família, passam ambos a se chamar amantes, assim sendo denominado seu estado civil. Desse modo, identificam-se com facilidade os que vivem em união estável. Não são casados nem solteiros, separados, divorciados ou viúvos. São amantes porque se amam e, com seu amor, formam uma união deafeto. O amor é o elemento constitutivo da união estável e deve servir para identificá-la. ${ }^{36}$

\footnotetext{
${ }^{34}$ LÔBO, Paulo. Direito Civil: Famílias. São Paulo: Saraiva, 2008. P. 1.

${ }^{35}$ MADALENO, Rolf. Curso de Direito de Família. $4^{\mathrm{a}}$ edição. Rio de janeiro: Forense, 2011. P.25.

${ }_{36}$ Dias, Maria Berenice, Sociedade de afeto. Disponível em: <http://www.mariaberenice.com.br/uploads/1_-_sociedade_de_afeto.pdf> Acesso em 23.03.14.
} 
Cumpre ressaltar que, apesar do Estado Brasileiro ser laico, este ainda sofre forte influência religiosa, interferindo na ordem social e determinando relações padronizadas através da cultura monogâmica. O legislador insiste em legislar visando a conservação da conduta moral e religiosa e não do ponto de vista que o ser humano é um ser social, estando em permanente modificação. ${ }^{37}$ Dessa forma, é preciso abandonar de vez os ranços patriarcais e patrimoniais do século XIX.

Neste sentido Paulo LÔBO elucida que: “A restauração da primazia da pessoa, nas relações de família, na garantia da realização da afetividade, é a condição primeira de adequação do direito à realidade. Esta mudança de rumos é inevitável"38. E conclui: "há de haver a minimização do patrimônio e a maximização da afetividade" ${ }^{39}$, de modo a reconhecer a supremacia do afeto como elemento constitutivo das diversas formas de entidades familiares.

\section{2 - O DEVER DE FIDELIDADE X LEALDADE}

Conforme já mencionado no ponto 1.3, o Código Civil de 2002, diferenciou os deveres impostos à união estável e ao casamento. Aos companheiros são estabelecidos os deveres de lealdade, respeito e assistência, elencados no art. 1.724, CC, enquanto no casamento são impostos os deveres de fidelidade recíproca, vida no domicílio conjugal e mútua assistência, estes elencados no art. 1.566, CC.

Note-se que o legislador não impôs às uniões estáveis o dever de fidelidade, mas assim o fez em relação ao casamento. Nos dizeres de Maria Berenice Dias:

\footnotetext{
${ }^{37}$ TEPEDINO, Gustavo. Temas de Direito Civil. Rio de Janeiro: Renovar, 2004, p. 372.

${ }^{38}$ LÔBO, Paulo Luiz Neto. A Repersonalização das Relações de Família. In: DEL’OLMO, Florisbal de Souza; ARAÚJO, Luís Ivani de Amorim (coords.). Direito de Família Contemporâneo e os novos direitos. Rio de Janeiro: Forense, 2006. P. 99 - 114.

${ }^{39}$ Idem, P. 152.
} 
Não se atina o motivo de ter o legislador substituído fidelidade por lealdade. Como na união estável é imposto tão só o dever de lealdade, pelo jeito inexiste a obrigação de ser fiel. Portanto, autorizando a lei a possibilidade de definir como entidade familiar a relação em que não há fidelidade nem coabitação, nada impede o reconhecimento de vínculos paralelos. Se os companheiros não tem o dever de serem fiéis nem de viverem juntos, a mantença de mais de uma união não desconfigura nenhuma delas. ${ }^{40}$

Segundo a doutrinadora, inexistindo a obrigação de fidelidade e coabitação nas uniões estáveis, a lei dá uma abertura para o reconhecimento de uniões estáveis paralelas. Contudo, a mesma realidade não se impõe ao casamento, haja vista o dever de fidelidade recíproca estabelecido pelo legislador civil.

Nesta linha, há alguns julgados entendendo que a infidelidade não exclui a possibilidade do reconhecimento de uma entidade familiar:

PROCESSUAL CIVIL. CERCEAMENTO DE DEFESA NAO CONFIGURADO. JULGAMENTO EXTRA PETITA NAO CARACTERIZADO. CONFIGURADOS OS REQUISITOS ENSEJADORES DA UNIÃO ESTÁVEL. MITIGAÇAO DAQUELES ATINENTES AO DEVER DE FIDELIDADE E DE COABITAÇAO. DIREITO DE MEAÇAO AOS BENS ADQUIRIDOS NA CONSTÂNCIA DA UNIÃO ESTÁVEL. RECURSO DESPROVIDO EM PARTE. SENTENÇA REFORMADA PARCIALMENTE. (...) 5 - A evolução em sede de direito de família, todavia, vem provocando a mitigação de alguns desses requisitos, em vista das inúmeras situações de fato recorrentes na sociedade contemporânea. 6 - Relativamente ao dever de fidelidade, leciona doutrinador gaúcho Arnaldo Rizzardo, em sua obra "Direito de Família" que não se configura como condição indispensável, pois nada impede que duas pessoas constituam um patrimônio comum, sem que mantenham a fidelidade ( $3^{\mathrm{a}}$ ed. Rio de Janeiro: Forense. 2005. p. 891$).(\ldots)^{41}$

\footnotetext{
${ }^{40}$ DIAS, Maria Berenice. Manual de Direito das Famílias. $8^{\mathrm{a}}$ edição. São Paulo: Revista dos Tribunais, 2011. P. 178.

${ }^{41}$ TJ-ES - AC: 35020077398 ES 035020077398, Relator: ARNALDO SANTOS SOUZA, Data de Julgamento: 13/05/2008, PRIMEIRA CÂMARA CÍVEL, Data de Publicação: 25/06/2008
} 
UNIÃO ESTÁVEL. EXCEPTIO PLURIUM

CONCUBENTIUM. A eventual infidelidade do varão durante o período de convivência com a autora não serve para desconfigurar a união estável e ensejar as seqüelas patrimoniais cabíveis. Apelo improvido. ${ }^{42}$

Entretanto, não é esse o posicionamento de grande parte da doutrina.

Esta entende que o dever de lealdade estabelecido aos companheiros compreende o dever de fidelidade. Então vejamos:

(...) a expressão 'fidelidade' é utilizada para identificar os deveres do casamento; e 'lealdade' tem sido a palavra utilizada para as relações de união estável, embora seja incontroverso o seu sentido único de ressaltar um comportamento moral e fático dos amantes casados ou conviventes, que têm o dever de preservar a exclusividade das suas relações como casal. ${ }^{43}$

$* * *$

A fidelidade é o dever de lealdade, sob o aspecto físico e moral, de um dos cônjuges para com o outro, quanto à manutenção de relações que visem à satisfação do instinto sexual dentro da sociedade conjugal. ${ }^{44}$

$$
* * *
$$

Entendemos que fidelidade é uma espécie do gênero lealdade. Impõe-se como dever dos companheiros em atendimento ao princípio jurídico da monogamia, que, por sua vez, funciona como um ponto chave das conexões morais. (...) A lealdade está intrinsecamente atrelada ao respeito, consideração ao companheiro e, principalmente, ao animus da preservação da relação marital. (...) A razão de se adotar lealdade, ao invés de fidelidade, é o intuito do legislador de acatar uma postura mais ampla e mais aberta, posto que não se restringe à questão sexual, mas abrange a exigência de honestidade mútua dos companheiros. $^{45}$

\footnotetext{
${ }^{42}$ Apelação Cível No 70000848887, Sétima Câmara Cível, Tribunal de Justiça do RS, Relator: Maria Berenice Dias, Julgado em 05/10/2000.

${ }^{43}$ MADALENO, Rolf. A União (Ins)Estável (Relações Paralelas). Disponível em: <http://www.flaviotartuce.adv.br/> Acesso em 27 abr. 2008.

${ }^{44}$ SANTOS, Regina Beatriz Tavares da Silva Papa dos. Responsabilidade Civil dos Cônjuges. IN: A Família na Travessia do Milênio. Anais do II Congresso Brasileiro de Direito de Família. IBDFAM. Belo Horizonte: Del Rey, 2000. P. 128.

${ }^{45}$ PEREIRA, Rodrigo da Cunha. Concubinato e União Estável. 7a ed. Belo Horizonte: Del Rey, 2004. p. 31 e 32.
} 
O dever de lealdade implica franqueza, consideração, sinceridade, informação e, sem dúvida, fidelidade. Numa relação afetiva entre homem e mulher, necessariamente monogâmica, constitutiva de família, além de um dever jurídico, a fidelidade é requisito natural. ${ }^{46}$

$* * *$

(...) devemos mencionar o dever de lealdade recíproca, pois a lealdade é figura de caráter moral e jurídico independentemente de cogitar-se da fidelidade, cuja inobservância leva ao adultério, que é figura estranha ao concubinato. É certo que não existe adultério entre companheiros; todavia, devem ser eles leais. A lealdade é gênero de que a fidelidade é espécie (...). Desse modo, a quebra do dever de lealdade, entre concubinos, implica injúria apta a motivar a separação de fato dos conviventes, dada a rescisão do contrato concubinário. ${ }^{47}$

Portanto, levando-se em consideração que adota-se o princípio monogâmico das relações afetivas no mundo ocidental, embora haja distinção terminológica, a doutrina majoritária, bem como a jurisprudência pátria entendem que a fidelidade figura entre os deveres inerentes tanto ao casamento quanto à união estável. Diante deste posicionamento jurídico, fecha-se os olhos para uma realidade social, limitando a proteção estatal às pessoas oriundas desse tipo de relacionamento, ferindo o princípio fundamental da dignidade da pessoa humana.

\section{3 - PRINCÍPIO X REGRA}

Embora a simultaneidade de conjugalidades suscite perplexidades, devida a nossa tradição cultural e religiosa, tal situação fática sempre esteve presente em nossa sociedade, sendo cada vez mais frequente a formação de entidades famíliares com tal característica.

\footnotetext{
${ }^{46}$ VELOSO, Zeno. Código Civil Comentado. Vol. XVII. Coord. Álvaro Villaça Azevedo. São Paulo: Atlas, 2003.p. 129.

${ }^{47}$ AZEVEDO, Álvaro Villaça. Estatuto da Família de Fato. 2a ed. São Paulo: Atlas, 2002. P. 189; 444.
} 
Nesse passo, a fim de identificar os limites e as possibilidades da aprrensão jurídica e da atribuição de eficácia a situações de simultaneidade familiares instituídas por meio de múltiplas conjugalidades concomitantes, é preciso fazer uma análise do universo principiológico que permeia essa temática. $^{48}$

Diante disso, inicia-se a análise principiológica pela problematização a respeito da existência ou não do princípio da monogamia no ordenamento jurpidico brasileiro, passível de ser imposto como um dever-ser a todas as formações de entidades familiares.

Primeiramente é necessário conceituar a monogamia. Trata-se de uma única conjugalidade dentro de uma mesma comunidade famíliar, pautanda na fidelidade e na exclusividade de um para com o outro. A monogamia nada mais é que uma construção histórico-sociológica que hoje representa um "padrão de conduta" da família ocidental capaz de gerar juízos morais por parte da sociedade tendentes à reprodução desse padrão.

Isso não significa dizer que "o direito de família, como expressão estatal, estaria a eleger esse padrão como o único passível de apreensão e tutela jurídicas, relegando comportamentos supostamente "desviantes" à mácula da ilicitude. ${ }^{" 49}$

Nesta seara, o Estado ao impôr que todas as relações familiares sejam monogâmicas, tratando o princípio da monogamia como um "deverser", estabelece um conflito com os princípios constitucionais da liberdade e da dignidade da pessoa humana. Destarte, a monogamia não se trata de uma regra que possa ser imposta à todas as pessoas, da mesma forma que não deve o Estado reputar ilícitas formas de convivência plurais decorrentes de escolhas coexistencias materialmente livres que são mais adequadas às suas aspirações pessoais e existenciais.

\footnotetext{
${ }^{48}$ PIANOVSKI, Carlos Eduardo. Famílias Simultâneas e monogamia. IN: Família e Dignidade Humana: Anais do V Congresso Brasileiro de Direito de Família . Rodrigo da Cunha (Coord). São Paulo: IBDFAM, 2006. P.194.

${ }^{49}$ Idem. P.196.
} 
A monogamia como regra das relações conjugais da família ocidental, enseja expectativa de lealdade, de comunhão de vidas, bem como a pretensão mútua de exclusivadade quanto ao relacionamento sexual. Nas palavras de Carlos Eduardo Pianovski: "não se pode afirmar, pois, que a monogamia seja um princípio do direito estatal de família, mas, sim, uma regra restrita à proibição de múltiplas relações matrimonializadas - e, portanto, constituídas sob a chancela prévia do Estado."50

Na medida em que o sentido da proteção jurídica da família mudou, passando a privilegiar o sujeito da relação em detrimento da instituição, consagrou-se princípios que norteiam o direito de família contemporâneo, como o princípio eudemonista, o princípio da liberdade e o princípio da pluralidade das entidades familiares. A busca pela felicidade, caracterizada pelo princípio eudemonista, por meio da constituição familiar, enfatiza o valor jurídico do afeto como base da relação familiar.

Já dizia o filósofo Aristóteles: "A felicidade é um princípio; é para alcançá-la que realizamos todos os outros atos; ela é exatamente o gênio de nossas motivações." ${ }^{51}$

Neste diaspasão, Flávio Tartuce ressalta o valor jurídico do afeto no âmbito do Direito de Família:

$\mathrm{O}$ afeto se mostra atualmente, como principal fundamento das relações familiares, mesmo não constando da Constituição da República Federativa do Brasil de 1988 como princípio fundamental, pode-se afirmar que ele advém do princípio maior da dignidade da pessoa humana e da solidariedade. ${ }^{52}$

Assim, é dever do Estado dar a devida proteção legal a família na pessoa de cada um de seus membros numa dimensão coexistencial, assegurando o desenvolvimento e a concretização da dignidade da pessoa humana. O princípio da boa-fé objetiva ganha relevância uma vez que

\footnotetext{
${ }^{50}$ Ibidem. P.198.

${ }^{51}$ Aristóteles, Ética a Nicômaco 1.12.8.

${ }^{52}$ TARTUCE, Flávio. Manual do Direito Civil. Volume Único. Rio de Janeiro: Forense. 2011. P. 992.
} 
quando o companheiro daquele que se encontra em um relacionamento paralelo a outro não tem conhecimento acerca da existencia desse outro núcleo familiar, a ele simultâneo e anterior, não se pode deixar de dar-lhe total proteção jurídica, vez que este desconhecia do estado impeditivo do outro de constituir uma união familiar.

Há contudo, casos em que a simultaneidade atende as pretensão de felicidade coexistencial de todos os componentes do núcleo familiar: o poliamor. Nos relacionamentos poliamorosos, a simultaneidade não é desleal, pois acredita-se que há a possibilidade de amar mais de uma pessoa, não sendo natural se privar do amor, apenas por uma convenção social. Dessa forma, todos os integrantes dessa entidade familiar aceitam e concordam com essa forma de se relacionar. São relacionamentos profundos, contínuos e duradouros, com o objetivo de constituição de família, mas que não se restringe àpenas dois integrantes.

Constata-se, portanto, que a monogamia é uma construção social ocidental, mantida ao longo dos anos com base em princípios éticos e morais. Com a evolução da sociedade, o direito de família contemporâneo tem como princípios vetores a pluralidade de entidades familiares, pautadas na liberdade de escolha e no eudemonismo, na qual o afeto é tido como um valor jurídico e um dos pilares da família contemporânea.

\section{AS FAMÍLIAS SIMULTÂNEAS}

\section{1 - CONCEITUANDO: O POLIAMOR E O PARALELISMO FAMILIAR}

O termo "Famílias Simultâneas" não é sinônimo de "Famílias Paralelas”. O primeiro é gênero, enquanto o segundo é espécie, ou seja, o termo "Famílias Simultâneas" é muito mais amplo, não se limitando ao paralelismo familiar. São inúmeras as possibilidades concretas de 
verificação de simultaneidade familiar, no entanto, vamos nos limitar à duas espécies:

- Denominado como "concubinato" pelo Código Civil, tais famílias são constituídas paralelamente à outra. Os relacionamentos ocorrem simultaneamnete e, em geral, ambas desconhem a situação de simultaneidade, agindo de boa-fé. Há, contudo, famílias que se formam havendo ciência da existência de outra união concomitante constituída previamente.

- O poliamor é o nome dado as relações afetivo-sexuais entre mais de duas pessoas, na qual os parceiros dessa relação acreditam que é possível amar mais de uma pessoa. Normalmente, os parceiros se relacionam somente entre si, incidindo um dever de "polifidelidade". Difere do "relacionamento aberto", haja vista que o poliamor necessariamente faz referência à não-monogamia afetiva, enquanto o "relacionamento aberto" faz referência à nãomonogamia sexual. Aqui, o conceito de fidelidade ganha nova acepção, não significando ter relação afetivo-sexual apenas com uma pessoa, mas sim ser sincero com quem se ama, ou seja, fiel ao "acordo" entre ambos os conviventes, seja ele qual for ou quantos forem.

- A poligamia ou a bigamia, são espécies consideradas como crime pelo ordenamento jurídico, previsto no art. 235 do Código Penal, na qual é proibido contrair matrimônio com alguém, já sendo casado com outrem, ou seja, simultaneamente. Ressalta-se que, apesar do impedimento civil, tal proibição de ordem criminal só leva em conta a instituição do casamento.

Dessa forma, cada espécie de família simultânea merece proteção jurídica estatal, uma vez que, apesar de fugir do convencional e de ser moralmente refutado por grande parte da sociedade, são formas de constituição de família cada vez mais presentes. 
No entanto, vamos dar um maior enfoque para a espécie de paralelismo familiar, mais conhecido como concubinato. Carlos Eduardo Pianovski também põe em evidência tal espécie:

Dentre as possibilidades de configuração de simultaneidade, avulta como alvo de maiores controvérsias aquela que se institui mediante duas ou mais relações concomitantes de conjugalidade - aqui tomada tanto em sua concepção formal matrimonializada quanto em sua formação como situação de fato. ${ }^{53}$

\section{2 - AS FAMÍLIAS PARALELAS NO ORDENAMENTO JURÍDICO BRASILEIRO}

A família ocidental tem como base a monogamia. O Código Penal, em seu art. 235, tipifica a bigamia - quando um indivíduo casado contrai matrimônio com outra pessoa - como conduta criminosa, sob pena de reclusão de 02 (dois) a 06 (seis) anos. O código Civil, em seu art. 1.723, $\S 1^{\mathrm{o}^{54}}$, a partir de uma interpretação analógica, vai mais além, proibindo a formação - ou ao menos o reconhecimento por parte do Estado - de uma união estável se ocorrem um dos impedimos do art. 1.521, do referido diploma legal.

Desse modo, incidindo o impedimento previsto o inciso $\mathrm{VI}^{55}$ do referido dispositivo, há um proibição fundada num impedimento legal de se constituir nova união, seja matrimonializada, seja de fato, se uma das partes já for casada com outrem.

A esse respeito diz Rolf Madaleno:

\footnotetext{
${ }^{53}$ PIANOVSKI, Carlos Eduardo. Famílias Simultâneas e monogamia. IN Família e Dignidade Humana: Anais do V Congresso Brasileiro de Direito de Família . Rodrigo da Cunha (Coord). São Paulo: IBDFAM, 2006. P.194.

${ }^{54} \S 1^{\circ}$ : A união estável não se constituirá se ocorrerem os impedimentos do art. 1.521; não se aplicando a incidência do inciso VI no caso de a pessoa casada se achar separada de fato ou judicialmente.

${ }^{55}$ Art. 1.521.: Não podem casar: VI - as pessoas casadas.
} 
Mas, segue sendo empecilho para a união estável a coexistência de um casamento paralelo e sujo cônjuge não está nem fática e nem legalmente desvinculado da relação precedente, mantendo uma união adulterina, veda pelo $\S 1^{\circ}$ do artigo 1.723 do Código Civil. ${ }^{56}$

O Código Civil de 2002 deu uma formatação ao concubinato em seu art. 1.727, indicando que "as relações não eventuais entre o homem e a mulher, impedidos de casar, constituem concubinato". O legislador civil teve unicamente a intenção de excluir as uniões simultâneas do conceito de entidade familiar. Além disso, não tratou de regular tal situação fática, apenas referindo-se à ela para vedar-lhes direitos.

É vedada, então, a prática dos seguintes atos em favor da concubina $^{57}:$ i) proibição de realizar doação em favor da concubina, sob pena de anulabilidade, no prazo de dois anos contados do término da relação conjugal, pelo outro cônjuge ou pelos herdeiros necessários (arts. 550 e 1.642,V, CC); ii) proibição de estipular seguro de vida em favor da concubina, sob pena de nulidade (art. 793, $\mathrm{CC}^{58}$ ); iii) proibição de contemplar como beneficiária de testamento, seja a título de herança ou de legado, sob pena de nulidade (art. 1.801, III, CC); e iv) impossibilidade da concubina receber alimentos (art. 1.694, CC).

É de se atentar que tais vedações se contrapõem com o princípio da autonomia da vontade, haja vista que impedem que o titular do patrimônio disponha de sua cota disponível. Nas palavras de Cristiano Chaves Farias e Nelson Rosenvald, “o proprietário pode dispor, respeitando o limite da legítima, beneficiando quem quiser, exceto a sua concubina, como se esta fosse responsável única pelo relacionamento amoroso"

\footnotetext{
${ }^{56}$ MADALENO, Rolf. Curso de Direito de Família. $4^{a}$ edição. Editora Forense, Rio de janeiro, 2011. P. 15

${ }^{57}$ FARIAS, Cristiano Chaves; ROSENVALD, Nelson. Curso de Direito Civil. Famílias. $4^{\mathrm{a}}$ Edição. Editora JusPodivm, 2012. P. 510-511.

${ }^{58}$ Art. 793.: É válida a instituição do companheiro como beneficiário, se ao tempo do contrato o segurado era separado judicialmente, ou já se encontrava separado de fato.

${ }^{59}$ FARIAS, Cristiano Chaves; ROSENVALD, Nelson. Curso de Direito Civil. Famílias. $4^{a}$ Edição. Editora JusPodivm. 2012. P. 511.
} 
Apesar da repulsa social e da invisibilidade aos olhos da lei, tais uniões existem e geram efeitos jurídicos, não podendo ser ignoradas pelo Poder Judiciário, sob pena de se cometer injustiças. Dessa forma, Helder Martinez Dal Col nos traz uma reflexão à esse respeito:

Talvez se tenha perguntado o legislador: - como chamar, agora, aquelas relações que apresentam características de união estável, mas que não o configuram, por impedimento incontornável? Que espécie de figura jurídica estará em tela, quando se tratar de companheira de homem casado, que com ele conviveu anos a fio, teve filhos e adquiriu patrimônio, muitas vezes sem nem imaginar que o companheiro possuísse família legítima, hipótese esta tão comum e repetidamente trazida à apreciação judicial? Poderá haver união estável concomitante ao casamento? ${ }^{60}$

Para Arnaldo Rizzardo, bem como para grande parte da doutrina, é “inaceitável que se considere legal uma união de fato que para o casamento signifique espúria, incestuosa ou adulterina."61. Na mesma linha, temos Rolf Madaleno e Rodrigo da Cunha Pereira:

Casamentos múltiplos são vedados, como proibidos os concubinatos paralelos, porque não se coaduna com a cultura brasileira uma união poligâmica ou poliândrica, a permitir multiplicidade de relações entre pessoas já antes comprometidas, vivendo mais de uma união ao mesmo tempo. $^{62}$

$* * *$

O artigo $1^{\circ}$ (Lei 9.278/96) já começa instalando polêmica quando define o que vem a ser união estável, termo substituto do estigmatizante "concubinato": "É reconhecida como entidade familiar a convivência duradoura, pública e contínua de um homem e uma mulher, estabelecida com o objetivo de constituição de família". Ao contrário da lei anterior (8.971/94), não deixa claro se os sujeitos dessa relação devem ser

\footnotetext{
${ }^{60}$ DAL COL, Helder Martinez. A união estável perante o novo código Civil. IN: CAHALI, Yussef Said; CAHALI, Francisco José (Coord.). Edições especias, 100 anos, Doutrinas Essenciais: Família e Sucessões, vol. II, Entidades Familiares. Revista dos Tribunais, 2011. P.1077

${ }^{61}$ RIZZARDO, Arnaldo. Direito de Família. $2^{\mathrm{a}}$ edição. Editora forense, 2004. P. 889.

${ }^{62}$ MADALENO, Rolf. Curso de Direito de Família. $4^{a}$ edição. Rio de janeiro: Forense, 2011. P.16.
} 
desimpedidos, ou seja, deixa em aberto o entendimento de que até pessoas casadas podem receber proteção do Estado para constituição dessas uniões. Neste sentido, seria a admissão da poligamia em nosso ordenamento jurídico. A confusão aumenta quando o art. $2^{\circ}$ suprime, de seu projeto original, a expressão "fidelidade", por "respeito e consideração mútuos". Ora, será que essa expressão pressupõe fidelidade? Com isto há margem para se pensar que a fidelidade não é pressuposto para a união estável, embora seja para o casamento. ${ }^{63}$

Tal posicionamento da doutrina não encontra respaldo no que concerne à putatividade. Havendo boa-fé de um dos conviventes, ou seja, em se provando que ele não sabia da existência concomitante de casamento constituído previamente à união deles, tais direitos devem ser resguardados. Assim, o reconhecimento estatal das uniões paralelas desenvolvidas com base no princípio da boa-fé tem sido fortemente defendido pelos doutrinadores do Direito de Família, como Vitor Hugo Oltramari e Renata Miranda Goecks ${ }^{64}$. É o que frisa Rolf Madaleno:

Não ingressam nesta afirmação os chamados concubinatos putativos, quando um dos conviventes age na mais absoluta boa-fé, deconhecendo que seu parceiro é casado e que também coabita com o seu cônjuge, porquanto a lei assegura os direitos patrimoniais gerados de uma união em que um dos conviventes foi laqueado em sua crença quanto a realidade dos fatos. (...) Cuida-se do erro de fato, desconhecendo o concubino a preexistência do casamento de seu parceiro e, sobretudo, ignorando que seu parceiro segue coabitando com seu cônjuge, sendo hábil o suficiente para dissimular uma separação de fato que em realidade não existe. ${ }^{65}$

Todavia, apesar da boa-fé e da crença na fidelidade do parceiro, ainda assim, a tendência é não reconhecer a existência de uma entidade

\footnotetext{
63 PEREIRA, Rodrigo da Cunha. Disponível em: <http://www.rodrigodacunha.adv.br/instituicaoda-poligamia/> Acesso em 26 abr. 2014.

${ }^{64}$ GOECKS, Renata Miranda e OLTRAMARI, Vitor Hugo. A possibilidade do reconhecimento da união estável putativa e paralela como entidade familiar, frente aos princípios constitucionais aplicáveis. In: MADALENO, Rolf e MILHORANZA, Mariângela Guerreiro (Coord.). Atualidades do Direito de Família e Sucessões. Sapucaia do Sul: Notadez, 2008. P.402.

${ }^{65}$ MADALENO, Rolf. Curso de Direito de Família. 4ª Edição. Editora Forense. 2001. P.15.
} 
familiar, mas tão somente uma sociedade de fato, alocando tais uniões no direito obrigacional e não no direito de família.

Em contrapartida, autores como Maria Berenice Dias e Carlos Cavalcanti de Albuquerque Filho ${ }^{66}$ apontam para a existência de uma crise do sistema monogâmico, sendo cada vez mais comum que o surgimento de diversos arranjos famíliares, não-monogâmicos, sejam tolerados pela sociedade.

Há que atentar que "apenas a afetividade, e não a lei, mantém unidas essas entidades familiares"67. Isto é, apesar de invisíveis aos olhos da lei, a existência de tais situações fáticas em nossa sociedade é indiscutível. Desse modo, segundo Mariana Chaves, o simples fato de existirem famílias constituídas simultaneamente à outra é fato gerador do dever do Estado de regular tais situações fáticas no âmbito jurídico:

Não é dever do Estado realizar algum juízo de reprovabilidade em face das relações conjugais plurais, pois tais relações se controem no âmbito dos fatos, cabe ao mesmo regular tais situações, e não fazer com que a sociedade fique estática simplismente por que as normas não dão conta das demandas sociais. ${ }^{68}$

Maria Berenice Dias evidencia consequências do não reconhecimento no âmbito sucessório:

São relações que repercutem no mundo jurídico, pois os companheiros convivem, muitas vezes têm filhos, e há construção patrimonial em comum. Não ver essa relação, não lhe outorgar qualquer efeito efeito, atenta contra a dignidade dos partícipes e filhos porventura existentes. Como não mais admite a Constituição tratamento discriminatório dos filhos,

\footnotetext{
${ }^{66}$ ALBUQUERQUE FILHO, Carlos Cavalcanti. Famílias Simultâneas e concubinato adulterino. In: PEREIRA, Rodrigo da Cunha (Coord.). família e cidadania, o novo CCB e a vacatio legis. Belo Horizonte: IBDFAM, Anais do III Congresso Brasileiro de Direito de Família, 2002, p.152153.

${ }^{67}$ LÔBO, Paulo Luiz Netto. Identidades familiares constitucionalizadas: para além do numerus clausus. Anais do III Congresso Brasileiro de Direito de Família. Belo Horizonte, 2002, p. 97.

68 CHAVES, Mariana. Famílias Paralelas. IBDFAM. 2009. Disponível em: <https://www.ibdfam.org.br/artigos/autor/Marianna\%20Chaves> Acesso em 24.03.14.
} 
negar à mãe os direitos decorrentes da união que a mesma manteve com o seu genitor é excluir o dieito sucessório do filho com relação a ela. Ou seja, deixar de reconhecer o direito da mãe, pela via inversa e reflexamente, é não reconhecer o direito que o filho teria à herança dela. Assim, mesmo que o filho não possa mais ser considerado ilegítimo, acaba sujeitando-se a tratamento diferenciado, que a justiça não pode chancelar. ${ }^{69}$

O não reconhecimento como entidades familiares gera enriquecimento ílicito por parte daquele que mantém o vínculo dúplice, sendo beneficiado ao ver-se desobrigado de quaisquer obrigações de ordem tanto afetiva quanto patrimonial com aquele com quem formou a segunda família. Outrossim, não cabe ao Estado realizar um juízo prévio e geral de reprovabilidade contra formações conjugais plurais não constituídas sob sua égide.

Não há dúvida, portanto, que a ocorrência destas uniões é uma realidade inquestionável, da qual decorre a necessidade de se abrigar, no âmbito do direito de família a possibilidade das uniões paralelas receberem o reconhecimento jurídico de uniões estáveis, e não somente sociedade de fato, no âmbito obrigacional.

Por ser uma realidade social inegável e, ainda, sem regulamentação legal, tais questões litigiosas, quando do término de uma relação paralela, seja pela morte de um dos companheiro, seja pela cessação da união ainda em vida, acabam sendo levadas para a apreciação do Poder Judiciário. Contudo, por ser um tema bastante controverso e polêmico, não há uma posição jurisprudencial uniforme no ordenamento jurídico brasileiro.

Majoritariamente, a posição dos Tribunais Brasileiros são no sentido de não ser possível o reconhecimento de uniões constituídas paralelamente ao casamento. Vejamos:

DIREITO DE FAMÍLIA. RELACIONAMENTO AFETIVO PARALELO AO CASAMENTO. IMPOSSIBILIDADE DE

\footnotetext{
${ }^{69}$ DIAS, Maria Berenice. Manual de Direito das Famílias. $8^{\mathrm{a}}$ edição. Editora revista dos Tribunais. 2011. São Paulo. P. 51-52.
} 
RECONHECIMENTO DE UNIÃO ESTÁVEL. PRINCÍPIO DA MONOGAMIA. RECURSO NÃO-PROVIDO. O relacionamento afetivo da apelante com o seu amado não se enquadra no conceito de união estável, visto que o princípio da monogamia, que rege as relações afetivas familiares, impede o reconhecimento jurídico de um relacionamento afetivo paralelo ao casamento. Neste contexto, por se encontrar ausente elemento essencial para a constituição da união estável, qual seja, ausência de impedimento matrimonial entre os companheiros, e como o pai dos apelados não se encontrava separado de fato ou judicialmente, conforme restou suficientemente demonstrado nos autos, não é possível se caracterizar o concubinato existente como uma união estável. Entender o contrário seria vulgarizar e distorcer o conceito de união estável, instituto jurídico que foi consagrado pela Constituição Federal de 1988 com a finalidade de proteger relacionamentos constituídos com fito familiar e, ainda, viabilizar a bigamia, já que é possível a conversão da união estável em casamento. Por fim, ainda que haja no Superior Tribunal de Justiça um precedente extremamente eloqüiente e em tudo assemelhado ao caso que se examina, que consiste no REsp $n^{\circ} 742.685$, do STJ, julgado em 04-08-2005, de que foi

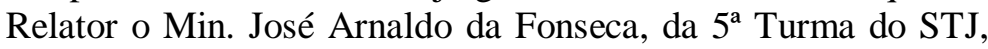
admitindo o direito à pensão previdenciária, deixo de apreciar o tema, visto que tal pleito há de ser formulado perante a Justiça Federal, visto que A.B.M., era Policial Rodoviário Federal, o que impede, por absoluta incompetência (artigo 109, inciso I, da Constituição da República), à Justiça Estadual reconhecer eventual direito previdenciário por parte da apelante. ${ }^{70}$

\section{$* * *$}

APELAÇÃO CÍVEL. AÇÃO DE RECONHECIMENTO E DISSOLUÇÃO DE UNIÃO ESTÁVEL COM PARTILHA DE BENS. RELACIONAMENTOS CONCOMITANTES. IMPOSSIBILIDADE. Cuida-se de ação de reconhecimento e dissolução de união estável, cumulada com pedido de partilha de bens. Conjunto probatório que aponta para a existência de dois relacionamentos concomitantes. União estável prévia, devidamente reconhecida em escritura pública entre a mãe e o pai da Ré, que impede o reconhecimento da alegada união entre a Autora e este último. O Superior Tribunal de Justiça ¿consagrou o entendimento de ser inadmissível o reconhecimento de uniões estáveis paralelas. Assim, se uma relação afetiva de convivência for caracterizada como união estável, as outras concomitantes, quando muito, poderão ser enquadradas como concubinato (ou sociedade de fato). Recurso

70 (Apelação Cível 1.0024.07.690802-9/001, Relator(a): Des.(a) Maria Elza , $5^{\text {a }}$ CÂMARA CÍVEL, julgamento em 18/12/2008, publicação da súmula em 21/01/2009) 
desprovido. $^{71}$

Essa corrente acredita que a legitimidade do relacionamento afetivo reside na possibilidade de a união identificar-se como uma família, não duas, três ou mais famílias, preservando os valores monogâmicos éticos, sociais, morais e religiosos da cultura ocidental. ${ }^{72}$

É neste sentido que vêm entendendo o Superior Tribunal de Justiça, afastando qualquer efeito jurídico às famílias paralelas. Vejamos:

Direito civil. Família. Recurso especial. Ação de reconhecimento de união estável. Casamento e concubinato simultâneos. Improcedência do pedido.

- A união estável pressupõe a ausência de impedimentos para o casamento, ou, pelo menos, que esteja o companheiro(a) separado de fato, enquanto que a figura do concubinato repousa sobre pessoas impedidas de casar.

- Se os elementos probatórios atestam a simultaneidade das relações conjugal e de concubinato, impõe-se a prevalência dos interesses da mulher casada, cujo matrimônio não foi dissolvido, aos alegados direitos subjetivos pretendidos pela concubina, pois não há, sob o prisma do Direito de Família, prerrogativa desta à partilha dos bens deixados pelo concubino.

- Não há, portanto, como ser conferido status de união estável a relação concubinária concomitante a casamento válido.

Recurso especial provido. ${ }^{73}$

DIREITO CIVIL. FAMÍLIA. PARALELISMO DE UNIÕES AFETIVAS. RECURSO ESPECIAL. AÇÕES DE RECONHECIMENTO DE UNIÕES ESTÁVEIS CONCOMITANTES. CASAMENTO VÁLIDO DISSOLVIDO. PECULIARIDADES. - Sob a tônica dos arts. 1.723 e 1.724 do CC/02, para a configuração da união estável como entidade familiar, devem estar presentes, na relação afetiva, os seguintes requisitos: (i) dualidade de sexos; (ii) publicidade; (iii) continuidade; (iv) durabilidade; (v) objetivo de constituição de família; (vi) ausência de impedimentos para o

71 APELAÇÃO no 0006502-19.2011.8.19.0210; DES. MARIO ROBERT MANNHEIMER; Julgamento: 23/05/2013; DECIMA SEXTA CAMARA CIVEL

${ }_{72}$ MADALENO, Rolf. Curso de Direito de Família. 4ª Edição. Editora Forense. 2001. P.24.

73 REsp 931155/RS, Rel. Ministra NANCY ANDRIGHI, TERCEIRA TURMA, julgado em 07/08/2007, DJ 20/08/2007, p. 281. 
casamento, ressalvadas as hipóteses de separação de fato ou judicial; (vii) observância dos deveres de lealdade, respeito e assistência, bem como de guarda, sustento e educação dos filhos. - A análise dos requisitos ínsitos à união estável deve centrar-se na conjunção de fatores presente em cada hipótese, como a affectio societatis familiar, a participação de esforços, a posse do estado de casado, a continuidade da união, a fidelidade, entre outros. - A despeito do reconhecimento - na dicção do acórdão recorrido - da "união estável" entre o falecido e sua ex-mulher, em concomitância com união estável preexistente, por ele mantida com a recorrente, certo é que já havia se operado - entre os ex-cônjuges - a dissolução do casamento válido pelo divórcio, nos termos do art. 1.571, § $1^{\circ}$, do $\mathrm{CC} / 02$, rompendo-se, em definitivo, os laços matrimoniais outrora existentes entre ambos. A continuidade da relação, sob a roupagem de união estável, não se enquadra nos moldes da norma civil vigente - art. 1.724 do CC/02 -, porquanto esse relacionamento encontra obstáculo intransponível no dever de lealdade a ser observado entre os companheiros. - O dever de lealdade "implica franqueza, consideração, sinceridade, informação e, sem dúvida, fidelidade. Numa relação afetiva entre homem e mulher, necessariamente monogâmica, constitutiva de família, além de um dever jurídico, a fidelidade é requisito natural" (Veloso, Zeno apud Ponzoni, Laura de Toledo. Famílias simultâneas: união estável e concubinato. Disponível em http://www.ibdfam.org.br/?artigos\&artigo=461. Acesso em abril de 2010). - Uma sociedade que apresenta como elemento estrutural a monogamia não pode atenuar o dever de fidelidade - que integra o conceito de lealdade - para o fim de inserir no âmbito do Direito de Família relações afetivas paralelas e, por conseqüência, desleais, sem descurar que o núcleo familiar contemporâneo tem como escopo a busca da realização de seus integrantes, vale dizer, a busca da felicidade. - As uniões afetivas plúrimas, múltiplas, simultâneas e paralelas têm ornado o cenário fático dos processos de família, com os mais inusitados arranjos, entre eles, aqueles em que um sujeito direciona seu afeto para um, dois, ou mais outros sujeitos, formando núcleos distintos e concomitantes, muitas vezes colidentes em seus interesses. - Ao analisar as lides que apresentam paralelismo afetivo, deve o juiz, atento às peculiaridades multifacetadas apresentadas em cada caso, decidir com base na dignidade da pessoa humana, na solidariedade, na afetividade, na busca da felicidade, na liberdade, na igualdade, bem assim, com redobrada atenção ao primado da monogamia, com os pés fincados no princípio da eticidade. - Emprestar aos novos arranjos familiares, de uma forma linear, os efeitos jurídicos inerentes à união estável, implicaria julgar contra o que dispõe a lei; isso porque o art. 1.727 do CC/02 regulou, em sua esfera de abrangência, as relações afetivas não eventuais em que se fazem presentes impedimentos para casar, de forma que só podem constituir concubinato os relacionamentos paralelos a casamento ou união estável pré e coexistente. Recurso especial provido. ${ }^{74}$

\footnotetext{
${ }^{74}$ STJ, Resp. n .157.273 - RN, Rel Min. Nancy Andrighi, 3a turma, public. 07/06/2010.
} 
Conquanto, tem sido cada vez mais frequente decisões judiciais reconhecendo direitos às uniões paralelas ao casamento. Para esta corrente, prevalesce o elemento afetivo, como o elo que enlaça a união adulterina ao campo do Direito de Família. Confere-se, portanto, após a ruptura da relação, a divisão do patrimônio conjugal entre três pessoas (triação do patrimônio), na razão de um terço dos bens de cada partícipe dessa relação.

$\mathrm{O}$ aresto abaixo transcrito é paradigmático a respeito desse entendimento:

\begin{abstract}
APELAÇÕES CÍVEIS. UNIÃO DÚPLICE. UNIÃO ESTÁVEL. PROVA. MEAÇÃO. 'TRIAÇÃO'. SUCESSÃO. PROVA DO PERÍODO DE UNIÃO E UNIÃO DÚPLICE. A prova dos autos é robusta e firme a demonstrar a existência de união entre a autora e o de cujus em período concomitante ao casamento do falecido. Reconhecimento de união dúplice paralela ao casamento. Precedentes jurisprudenciais. MEAÇÃO (TRIAÇÃO). Os bens adquiridos na constância da união dúplice são partilhados entre as companheiras e o de cujus. Meação que se transmuda em triação, pela duplicidade de vínculos familiares. Negaram provimento ao primeiro apelo e deram parcial provimento ao segundo. ${ }^{75}$
\end{abstract}

Além disso, já há decisões ordenando o pagamento duplo de pensão alimentícia e também ordenando a divisão da previdência social entre a esposa e a outra companheira. Em especial, os Tribunais do Rio Grande do Sul e de Minas Gerais vêm proferindo decisões em favor do reconhecimento jurídico de tais uniões. Vejamos:

APELAÇÃO. UNIÃO ESTÁVEL PARALELA AO CASAMENTO. RECONHECIMENTO. PARTILHA. "TRIAÇÃO". ALIMENTOS PARA EX-COMPANHEIRA E PARA O FILHO COMUM. Viável reconhecer união estável paralela ao casamento. Precedentes jurisprudenciais. Caso em que restou cabalmente demonstrada a existência de união estável entre as partes, consubstanciada em contrato particular assinado pelos companheiros e por 03 testemunhas; e ratificada

${ }^{75}$ ApC N. ${ }^{\circ}$ 70027512763, 8a Câmara Cível, TJRS, Relator: Rui Portanova, Julgado em $14 / 05 / 2009$. 
pela existência de filho comum, por inúmeras fotografias do casal junto ao longo dos anos, por bilhetes e mensagens trocadas, por existência de patrimônio e conta-bancária conjunta, tudo a demonstrar relação pública, contínua e duradoura, com claro e inequívoco intento de constituir família e vida em comum. Reconhecimento de união dúplice que impõe partilha de bens na forma de "triação", em sede de liquidação de sentença, com a participação obrigatória da esposa formal. Precedentes jurisprudenciais. Ex-companheira que está afastada há muitos anos do mercado de trabalho, e que tem evidente dependência econômica, inclusive com reconhecimento expresso disso no contrato particular de união estável firmado entre as partes. De rigor a fixação de alimentos em prol dela. Adequado o valor fixado a título de alimentos em prol do filho comum, porquanto não comprovada a alegada impossibilidade econômica do alimentante, que inclusive apresenta evidentes sinais exteriores de riqueza. APELO DO RÉU DESPROVIDO. APELO DA AUTORA PROVIDO. EM MONOCRÁTICA. (SEGREDO DE JUSTIÇA) - DECISÃ̃ MONOCRÁTICA . ${ }^{76}$

APELAÇÃO. UNIÃO DÚPLICE. UNIÃO ESTÁVEL. POSSIBILIDADE. A prova dos autos é robusta e firme a demonstrar a existência de união entre a autora e o de cujus em período concomitante ao casamento de "papel". Reconhecimento de união dúplice. Precedentes jurisprudenciais. Os bens adquiridos na constância da união dúplice são partilhados entre a esposa, a companheira e o de cujus. Meação que se transmuda em "triação", pela duplicidade de uniões. DERAM PROVIMENTO, POR MAIORIA, VENCIDO O DES. RELATOR. ${ }^{77}($

EMBARGOS INFRINGENTES. UNIÃO ESTÁVEL PARALELA AO CASAMENTO. RECONHECIMENTO. Ainda que o falecido não tenha se separado de fato e nem formalmente da esposa, existindo a convivência pública, contínua, duradoura e o objetivo de constituir família com a companheira, há que se reconhecer a existência da união estável paralela ao casamento. O aparente óbice legal representado pelo $\S 1^{\circ}$ do art. 1723 do Código Civil fica superado diante dos princípios fundamentais consagrados pela Constituição Federal de 1988, principalmente os da dignidade e da igualdade.

\footnotetext{
${ }^{76}$ TJRS, Apelação Cível No 70039284542 , Oitava Câmara Cível, Tribunal de Justiça do RS, Relator: Rui Portanova, Julgado em 23/12/2010.

${ }^{77}$ Apelação Cível N ${ }^{\circ}$ 70019387455, Oitava Câmara Cível, Tribunal de Justiça do RS, Relator: Luiz Ari Azambuja Ramos, Julgado em 24/05/2007. Publicação: Diário da Justiça do dia 21/06/2007.
} 
EMBARGOS INFRINGENTES DESACOLHIDOS, POR MAIORIA. $^{78}$

DIREITO DAS FAMÍLIAS. UNIÃO ESTÁVEL CONTEMPORÂNEA A CASAMENTO. UNIÃO DÚPLICE. POSSIBILIDADE DE RECONHECIMENTO FACE ÀS PECULIARIDADES DO CASO. RECURSO PARCIALMENTE PROVIDO. Ao longo de vinte e cinco anos, a apelante e o apelado mantiveram um relacionamento afetivo, que possibilitou o nascimento de três filhos. Nesse período de convivência afetiva - pública, contínua e duradoura - um cuidou do outro, amorosamente, emocionalmente, materialmente, fisicamente e sexualmente. Durante esses anos, amaram, sofreram, brigaram, reconciliaram, choraram, riram, cresceram, evoluíram, criaram os filhos e cuidaram dos netos. Tais fatos comprovam a concreta disposição do casal para construir um lar com um subjetivo ânimo de permanência que o tempo objetivamente confirma. Isso é família. $O$ que no caso é polêmico é o fato de o apelado, à época dos fatos, estar casado civilmente. Há, ainda, dificuldade de o Poder Judiciário lidar com a existência de uniões dúplices. Há muito moralismo, conservadorismo e preconceito em matéria de Direito de Família. No caso dos autos, a apelada, além de compartilhar o leito com o apelado, também compartilhou a vida em todos os seus aspectos. Ela não é concubina - palavra preconceituosa mas companheira. Por tal razão, possui direito a reclamar pelo fim da união estável. Entender o contrário é estabelecer um retrocesso em relação a lentas e sofridas conquistas da mulher para ser tratada como sujeito de igualdade jurídica e de igualdade social. Negar a existência de união estável, quando um dos companheiros é casado, é solução fácil. Mantém-se ao desamparo do Direito, na clandestinidade, o que parte da sociedade prefere esconder. Como se uma suposta invisibilidade fosse capaz de negar a existência de um fato social que sempre aconteceu, acontece e continuará acontecendo. A solução para tais uniões está em reconhecer que ela gera efeitos jurídicos, de forma a evitar irresponsabilidades e o enriquecimento ilícito de um companheiro em desfavor do outro. ${ }^{79}$

\footnotetext{
${ }^{78}$ Embargos Infringentes $N^{\circ} 70020816831$, Quarto Grupo de Câmaras Cíveis, Tribunal de Justiça do RS, Relator: Ricardo Raupp Ruschel, Julgado em 14/09/2007. Publicação: Diário da Justiça do dia 19/10/2007.

${ }_{79}$ Apelação Cível 1.0017.05.016882-6/003, Relator(a): Des.(a) Maria Elza , 5ª CÂMARA CÍVEL, julgamento em 20/11/2008, publicação da súmula em 10/12/2008.
} 
Em trecho de decisão ${ }^{80}$ reconhecendo a simultâneidade de união estável ao casamento, o Des. Rui Portanova, da oitava Câmara Cível do Tribunal de Justiça do Rio Grande do Sul evidencia:

(...) Não é de hoje, que tenho entendido possível o reconhecimento das uniões paralelas ou uniões dúplices. Tenho sustentado que, se a partir do cotejo dos elementos específicos que o caso concreto apresenta, restarem evidenciados os requisitos caracterizadores da união estável (art. 1.723 do CC), considero o reconhecimento da segunda união, em concomitância ao casamento, ser a medida mais adequada à realidade e ao estágio atual de convivência entre as pessoas em nossa sociedade. O contrário disso, é fechar os olhos a uma realidade que cada vez mais tem batido à porta do Judiciário, não sendo possível o Estado deixar de dar a devida tutela a toda uma história de vida das pessoas envolvidas no litígio, sob pena de causar uma grave injustiça. (...) Nesse sentido, a título de contribuição para o entendimento ora defendido, interessante colacionar as palavras da Desa. Maria Berenice Dias, em voto proferido no julgamento da $\mathrm{AC} \mathrm{n}^{0} 70017045733$, in verbis: "O ordenamento civil, consubstanciado no princípio da monogamia, não reconhece efeitos à união estável quando um do par ainda mantém íntegro o casamento (art. $1.723, \S 1^{\circ}$, do Código Civil). Certamente, esse é o ideal da sociedade: um relacionamento livre de toda a ordem de traições e, se possível, eterno até que "a morte os separe". Contudo, a realidade que se apresenta é diversa, porquanto comprovada a duplicidade de células familiares. E conferir tratamento desigual a essa situação fática importaria grave violação ao princípio da igualdade e da dignidade da pessoa humana. O Judiciário não pode se esquivar de tutelar as relações baseadas no afeto, não obstante as formalidades muitas vezes impingidas pela sociedade para que uma união seja "digna" de reconhecimento judicial.

80 APELAÇÃO CÍVEL. RECONHECIMENTO DE UNIÃO ESTÁVEL PARALELA AO CASAMENTO E OUTRA UNIÃO ESTÁVEL. UNIÃO DÚPLICE. POSSIBILIDADE. PARTILHA DE BENS. MEAÇÃO. "TRIAÇÃO ". ALIMENTOS. A prova dos autos é robusta e firme a demonstrar a existência de união estável entre a autora e o réu em período concomitante ao seu casamento e, posteriormente, concomitante a uma segunda união estável que se iniciou após o término do casamento. Caso em que se reconhece a união dúplice. Precedentes jurisprudenciais. Os bens adquiridos na constância da união dúplice são partilhados entre a esposa, a companheira e o réu. Meação que se transmuda em "triação", pela duplicidade de uniões. O mesmo se verificando em relação aos bens adquiridos na constância da segunda união estável. Eventual período em que o réu tiver se relacionado somente com a apelante, o patrimônio adquirido nesse período será partilhado à metade. Assentado o vínculo familiar e comprovado nos autos que durante a união o varão sustentava a apelante, resta demonstrado os pressupostos da obrigação alimentar, quais sejam, as necessidades de quem postula o pensionamento e as possibilidades de quem o supre. Caso em que se determina o pagamento de alimentos em favor da ex-companheira. APELAÇÃO PARCIALMENTE PROVIDA. (SEGREDO DE JUSTIÇA) (Apelação Cível No 70022775605, Oitava Câmara Cível, Tribunal de Justiça do RS, Relator: Rui Portanova, Julgado em 07/08/2008) Publicação: Diário da Justiça do dia 18/08/2008. 
Dessa forma, não obstante os Tribunais Superiores Brasileiros ainda entenderem não ser possível o reconhecimento de uniões simultâneas como entidades familiares, há cada vez mais decisões em primeira e segunda instância de diversos Tribunais Brasileiros, principalmente os do Rio Grande do Sul e Minas Gerais, adotando o entendimento, à luz de uma interpretação baseada no princípio constitucional da dignidade da pessoa humana, de que a existência concomitante do casamento não impede o reconhecimento da união estável, configurando o que a jurisprudência pátria convencionou chamar de "união dúplice".

\section{3 - AS UNIÕES ESTÁVEIS PARALELAS NO ORDENAMENTO JURÍDICO BRASILEIRO}

O código Civil, em seu art. 1.727, define o concubinato como sendo as "relações eventuais entre o homem e a mulher, impedidos de casar". Já o art. $1.521, \mathrm{VI}^{81}$, do mesmo dispositivo legal, é taxativo, ao impedir pessoas casadas de contrair matrimônio, simultâneamente. Da mesma forma, há esse impedimento em relação à constituição de união estável (CC $\left.1723^{82}\right)$. Observa-se, portanto, haver uma proibição legal em constituir nova união paralela ao casamento. No entanto, tal impedimento não alberga a formação de uniões estáveis paralelas à outra união estável.

O legislador ao reconhecer a união estável como forma de entidade familiar, não previu, ou ao menos, não regulamentou, situações de concomitância de relacionamentos afetivos com todas as características de

\footnotetext{
${ }^{81}$ Art. 1.521. Não podem casar:

$\mathrm{VI}$ - as pessoas casadas.

${ }^{82}$ Art. 1.723. É reconhecida como entidade familiar a união estável entre o homem e a mulher, configurada na convivência pública, contínua e duradoura e estabelecida com o objetivo de constituição de família.

$\S 1^{\underline{0}} \mathrm{~A}$ união estável não se constituirá se ocorrerem os impedimentos do art. 1.521; não se aplicando a incidência do inciso VI no caso de a pessoa casada se achar separada de fato ou judicialmente.
} 
união estável. Esse cenário é bastante costumeiro na realidade social, tendo sido cada vez mais comum demandas requerendo o reconhecimento de tais situações fáticas no judiciário brasileiro.

A realidade se impõe, apesar de permanecer num limbo jurídico. Dessa forma, a doutrina e a jurisprudência se dividem a fim de regulamentar essas figuras familiares, de modo a evitar prejuízos às partes.

A doutrina majoritária se posiciona tendo como fundamento o princípiro da monogamia como um preceito básico e organizador das relações jurídicas da família brasileira ${ }^{83}$. Para esses doutrinadores, a monogamia decorre de valores culturais, econômicos e religiosos, ${ }^{84}$ da cultura ocidental, de influência cristã, estendendo-se também para a configuração da união estável a exclusividade do relacionamento.

Assim, segundo essa corrente, a união estável se equipara de todo modo ao casamento, devendo-se interpretar a lógica do art. 1.521, VI, CC, analogicamente, nos casos de constituição de união estável paralelamente à outra previamente constituída. É o que afirma Marco aurélio S. Viana ao rebelar-se contra o concubinato:

O contingente moral que a união estável exige, pois o que se tem é uma aparência de casamento, os deveres que dela promanam, a sua relevância como forma de constituir uma família, todos esses fatores autorizam dizer que o concubinato múltiplo jamais poderá gerar efeitos, não merecendo a tutela da legislação especial. ${ }^{85}$

No entanto, esse posicionamento, embora ainda majoritario, não é pacífico, tampouco unânime, havendo diversos doutrinadores que defendem a dualidade de relacionamentos estáveis, já havendo, inclusive, decisões admitindo tais situações e protegendo as partes que as integram.

\footnotetext{
${ }^{83}$ PEREIRA, Rodrigo da Cunha. Princípios fundamentais norteadores do direito de família. Belo Horizonte. Editora Del Rey. 2006. P.107.

${ }^{84}$ MOTTA, Carlos Dias. Direito matrimonial e seus princípios jurídicos. São Paulo: RT, 2006. P.268.

${ }^{85}$ VIANA, Marco Aurélio S. Da União Estável. São Paulo: Saraiva, 1999. P. 92.
} 
Maria Berenice Dias é umas das doutrinadoras que possuem esse olhar discordante da maioria, defendendo a divisão do patrimônio entre três partes iguais:

Sendo duas uniões estáveis, e não se conseguindo definir a prevalência de uma relação sobre a outra, cabe a divisão do acervo patrimonial amealhado durante o período de convivência em três partes iguais, restando um terço para o varão e um terço para cada uma das companheiras. Cada um tem direito ao que Rui Portanova chama de triação. ${ }^{86}$

Nesta mesma linha, ressaltam Cristiano Chaves de farias e Nelson Rosenvald:

\begin{abstract}
Assim, parece-nos que é chegado o momento de refletir sobre o concubinato com o olhar mais atrelado à afetividade do que ao preconceito. Se o fundamento contemporâneo da relação familiar é a presença do afeto, o tratamento jurídico do concubinato reclama uma maior atenção e um debate mais cuidadoso. ${ }^{87}$
\end{abstract}

Assim, apesar de tais relações estarem sujeitas à reprovação social, não há um meio capaz de coibir sua formação. Como elas existem - e sempre existiram - não podemos ignorá-las. A falta de proteção estatal acarreta na não geração de direitos e deveres, e consequentemente, uma das partes sai prejudicada. É o que afirma Maria Berenice Dias:

Rejeitar qualquer efeito a esses vínculos e condená-los à invisibilidade gera irresponsabilidades e senseja o enriquecimento ilícito de um em desfavor do outro. O resultado é mais do que desastroso, é perverso: nega divisão de patrimônio, desonera de obrigação alimentar, exclui direito sucessório. Com isso, nada mais se estará fazendo do que incentivaro surgimento desse tipo de união. Estar à margem do direito traz benefícios, pois não impõe nenhuma obrigação. Quem vive com alguém por muitos anos necessita dividir bens

\footnotetext{
${ }^{86}$ DIAS, Maria Berenice. Manual de Direito das Famílias. $8^{\text {a }}$ edição. Editora revista dos Tribunais. 2011. São Paulo. P. 53.

${ }^{87}$ FARIAS, Cristiano Chaves de; ROSENVALD, Nelson. Curso de Direito Civil. Famílias. Editora JusPodivam. $4^{\circ}$ edição. 2012. P. 511.
} 
e pagar alimentos. Todavia, àquele que vive do modo que a lei desaprova, simplismente, não advém qualquer responsabilidade encargo ou ônus. Quem assim age, em vez de ser punido, sai privilegiado. Não sofre qualquer sanção e acaba sendo premiado. $^{88}$

\author{
Contudo, nem o $\mathrm{STJ}^{89}$ nem o $\mathrm{STF}^{90}$ reconhecem a existência de \\ uniões estáveis concomitantes. Não obstante a jurisprudência das Cortes \\ Superiores permaneça, majoritariamente, no sentido de negar efeitos \\ familiares às uniões concubinárias, é possível encontrarmos decisões \\ isoladas em alguns Tribunais brasileiros que levam em conta o carater \\ afetivo das relações familiares para enquadrar as uniões paralelas no \\ continente do Direito das Famílias. Vejamos:
}

UNIÃO ESTÁVEL. RECONHECIMENTO. DUPLICIDADE DE CÉLULAS FAMILIARES. O Judiciário não pode se esquivar de tutelar as relações baseadas no afeto, inobstante as formalidades muitas vezes impingidas pela sociedade para que uma união seja "digna" de reconhecimento judicial. Dessa forma, havendo duplicidade de uniões estáveis, cabível a

\footnotetext{
88 DIAS, Maria Berenice. Manual de Direito das Famílias. $8^{\text {a }}$ edição. Editora revista dos Tribunais. 2011. São Paulo. P. 176.

${ }^{89}$ DIREITO DE FAMÍLIA. RECONHECIMENTO DE UNIÕES ESTÁVEIS SIMULTÂNEAS. IMPOSSIBILIDADE. EXCLUSIVIDADE DE RELACIONAMENTO SÓLIDO. CONDIÇÃO DE EXISTÊNCIA JURÍDICA DA UNIÃO ESTÁVEL. EXEGESE DO $\S 1^{\circ}$ DO ART. 1.723 DO CÓDIGO CIVIL DE 2002. 1. Para a existência jurídica da união estável, extrai-se, da exegese do $\S$ $1^{\circ}$ do art. 1.723 do Código Civil de 2002, fine, o requisito da exclusividade de relacionamento sólido. Isso porque, nem mesmo a existência de casamento válido se apresenta como impedimento suficiente ao reconhecimento da união estável, desde que haja separação de fato, circunstância que erige a existência de outra relação afetiva factual ao degrau de óbice proeminente à nova união estável. 2. Com efeito, a pedra de toque para o aperfeiçoamento da união estável não está na inexistência de vínculo matrimonial, mas, a toda evidência, na inexistência de relacionamento de fato duradouro, concorrentemente àquele que se pretende proteção jurídica, daí por que se mostra inviável o reconhecimento de uniões estáveis simultâneas. 3. Havendo sentença transitada em julgado a reconhecer a união estável entre o falecido e sua companheira em determinado período, descabe o reconhecimento de outra união estável, simultânea àquela, com pessoa diversa. 4. Recurso especial provido. (STJ, Resp no 912.926 - RS, Rel Ministro Luis Felipe Salomão, 4 turma, pub. 07/06/2011).

${ }^{90}$ COMPANHEIRA E CONCUBINA - DISTINÇÃO. Sendo o Direito uma verdadeira ciência, impossível é confundir institutos, expressões e vocábulos, sob pena de prevalecer a babel. UNIÃO ESTÁVEL - PROTEÇÃO DO ESTADO. A proteção do Estado à união estável alcança apenas as situações legítimas e nestas não está incluído o concubinato. PENSÃO - SERVIDOR PÚBLICO MULHER - CONCUBINA - DIREITO. A titularidade da pensão decorrente do falecimento de servidor público pressupõe vínculo agasalhado pelo ordenamento jurídico, mostrando-se impróprio o implemento de divisão a beneficiar, em detrimento da família, a concubina. (RE 590779, Relator(a): Min. MARCO AURÉLIO, Primeira Turma, julgado em 10/02/2009).
} 
partição do patrimônio amealhado na concomitância das duas relações. Negado provimento ao apelo. ${ }^{91}$

\section{$* * *$}

APELAÇÃO CÍVEL. 1)UNIÃO ESTÁVEL PARALELA A OUTRA UNIÃO ESTÁVEL. RECONHECIMENTO. O anterior reconhecimento judicial de união estável entre o falecido e outra companheira, não impede o reconhecimento da união estável entre ele e autora, paralela àquela, porque o Direito de Família moderno não pode negar a existência de uma relação de afeto que também se revestiu do mesmo caráter de entidade familiar. Preenchidos os requisitos elencados no art. 1.723 do CC, procede a ação, deferindo-se à autora o direito de perceber $50 \%$ dos valores recebido a título de pensão por morte pela outra companheira. 2)RESSARCIMENTO DE DANOS MATERIAIS E EXTRAPATRIMONIAIS. Descabe a cumulação de ação declaratória com ação indenizatória, mormente considerando-se que o alegado conluio, lesão e má-fé dos réus na outra ação de união estável já julgada deve ser deduzido em sede própria. (SEGREDO DE JUSTIÇA) Apelação parcialmente provida. ${ }^{92}$

APELAÇÃO. UNIÃO DÚPLICE. UNIÃO ESTÁVEL. PROVA. MEAÇÃO. "TRIAÇÃO" . SUCESSÃO. PROVA DO PERÍODO DE UNIÃO E UNIÃO DÚPLICE A prova dos autos é robusta e firme a demonstrar a existência de união entre a autora e o de cujus em período concomitante a outra união estável também vivida pelo de cujus. Reconhecimento de união dúplice. Precedentes jurisprudenciais. MEAÇÃO (TRIAÇÃO) Os bens adquiridos na constância da união dúplice são partilhados entre as companheiras e o de cujus. Meação que se transmuda em "triação", pela duplicidade de uniões. DERAM PROVIMENTO À APELAÇÃO. POR MAIORIA. ${ }^{93}$

Nesta mesma linha, ressalta o magistrado Luís Cláudio Cabral Chaves, juiz da $4^{\text {a }}$ Vara de Família e Sucessões de Manaus, ao reconhecer a união estável simultânea de um homem com duas mulheres, após a morte dele, em decisão recente:

\footnotetext{
${ }^{91}$ Apelação Cível No 70010787398, Sétima Câmara Cível, Tribunal de Justiça do RS, Relator: Maria Berenice Dias, Julgado em 27/04/2005.

${ }^{92}$ Apelação Cível No 70012696068, Oitava Câmara Cível, Tribunal de Justiça do RS, Relator: José Ataídes Siqueira Trindade, Julgado em 06/10/2005

${ }_{93}$ Apelação Cível No 70011258605, Oitava Câmara Cível, Tribunal de Justiça do RS, Relator: Rui Portanova, Julgado em 25/08/2005
} 
Deixar de reconhecê-las não fará com que deixem de existir. Não se pode permitir que em nome da moral se ignore a ética, assim como que dogmas culturais e religiosos ocupem o lugar da Justiça até porque o Estado brasileiro é laico, segundo a Constituição Federal. ${ }^{94}$

Com efeito, o Judiciário não pode se esquivar de tutelar as relações baseadas no afeto, não obstante as formalidades muitas vezes impingidas pela sociedade para que uma união seja 'digna' de reconhecimento judicial. Conferir tratamento desigual a essa situação fática importaria grave violação ao princípio da igualdade e da dignidade da pessoa humana.

Evidenciados os requisitos caracterizadores da união estável (CC 1.723), ainda que haja concomitância de relacionamentos, a medida mais adequada à realidade e ao estágio de convivência entre as partes que compõe o relacionamento, é o reconhecimento destas como entidade familiar, à serem tratadas no âmbito do Direito de Família.

\section{4 - A QUESTÃO PREVIDENCIÁRIA}

No âmbito da legislação previdenciária, mais especificamente o decreto $\mathrm{n}^{\mathrm{o}} 3.048 / 1999$, o legislador também se posiciona com base na monogamia dos relacionamentos afetivos, no sentido de não beneficiar a companheira de um segurado casado. É o que se observa na leitura do art. 16, $\S 3^{\circ}$, da Lei n. 8.213/1991, in verbis:

$\S \mathbf{3}^{\mathbf{0}}$ : Considera-se companheira ou companheiro a pessoa que, sem ser casada, mantém união estável com o segurado ou com a segurada, de acordo com o $\S 3^{\circ}$ do art. 226 da Constituição Federal.

\footnotetext{
${ }^{94}$ <http://www.ibdfam.org.br/noticias/4995/novosite>
} 
Todavia, a doutrina previdenciária não entende desta forma, haja vista o caráter econômico e alimentar do Direito Previdenciário. Há inclusive, súmula jurisprudêncial do TFR, $\mathrm{n}^{\circ}$ 159, editada em 06 de junho de 1984, entendendo que "é legitima a divisão da pensão previdenciária entre a esposa e a companheira, atendidos os requisitos exigidos."

Arnaldo Rizzardo frisa que não há uma proibição legal que impeça o segurado casado de inscrever sua concubina como sua dependente e, portanto, beneficiária do seguro da Previdência Social:

\begin{abstract}
De realçar que não se proíbe ao segurado casado realizar a inscrição da companheira, e assim vice-versa. Por conseguinte, não se requer que, antes de se proceder a inscrição, se procure legalizar a separação de fato eventualmente existente, o que já era assim no regime anterior, que autorizava a inscrição de companheira ou companheiro de par ainda casado. A redação original do $\S 5^{\circ}$ do art. 22 do Decreto 3.048 proibia a inscrição de companheiro ou companheira por pessoa casada. No entanto, o dispositivo veio a ser revogado pelo Decreto $\mathrm{n}^{\circ} 4.079$, de 9.01.2002. ${ }^{95}$
\end{abstract}

Dessa forma, tendo em vista que a finalidade da previdência social é de garantir a subsistência dos seus beneficiários, se o segurado casado sustenta sua companheira/concubina da mesma forma que sustenta a sua esposa, ambas devem ser protegidas pela previdência social, após sua morte. Assim, tal ramo do Direito merece interpretação própria sob pena de não ser atingida a finalidade e função previdenciária ${ }^{96}$.

Vale ressaltar, no entanto, que somente haverá o rateio entre a concubina do segurado casado e sua esposa se ambas forem economicamente dependente do de cujus. Vejamos:

PREVIDENCIÁRIO. PENSÃO POR MORTE. ESPOSA E CONCUBINA. RATEIO. POSSIBILIDADE. 1. Para a concessão do benefício de pensão por morte, no caso de companheira, há necessidade de comprovação de união estável.

\footnotetext{
${ }^{95}$ RIZZARDO, Arnaldo. Direito de Família. Editora Forense. 2004. $2^{\text {a }}$ edição. P. 907.

${ }^{96}$ MADALENO, Rolf. Curso de Direito de Família. 4ª Edição. Editora Forense. 2001. P. 1.097.
} 
2. Na hipótese, ainda que verificada a ocorrência do concubinato impuro, não se pode ignorar a realidade fática, concretizada pela longa duração da união do falecido com a concubina, ainda que existindo simultaneamente dois relacionamentos, razão pela qual é de ser deferida à autora o benefício de pensão por morte na quota-parte que lhe cabe, a contar do ajuizamento da ação. ${ }^{97}$

A jurisprudência do Superior Tribunal de Justiça não é uniforme no tocante à esse tema. Contudo, tem se posicionado majoritariamnete no sentido da impossibilidade do rateio. Vejamos:

PREVIDENCIÁRIO. PENSÃO POR MORTE. COMPARTILHAMENTO DA PENSÃO ENTRE A VIÚVA E CONCUBINA. IMPOSSIBILIDADE. CONCOMITÂNCIA ENTRE CASAMENTO E CONCUBINATO ADULTERINO IMPEDE A CONSTITUIÇÃO DE UNIÃO ESTÁVEL, PARA FINS PREVIDENCIÁRIOS. RECURSO ESPECIAL PROVIDO.

1. Para fins previdenciários, há união estável na hipótese em que a relação seja constituída entre pessoas solteiras, ou separadas de fato ou judicialmente, ou viúvas, e que convivam como entidade familiar, ainda que não sob o mesmo teto.

2. As situações de concomitância, isto é, em que há simultânea relação matrimonial e de concubinato, por não se amoldarem ao modelo estabelecido pela legislação previdenciária, não são capazes de ensejar união estável, razão pela qual apenas a viúva tem direito à pensão por morte.

3. Recurso especial provido ${ }^{98}$

$* * *$

PREVIDENCIÁRIO. CONCUBINATO ADULTERINO. RELAÇÃO CONCORRENTE COM O CASAMENTO. EMBARAÇO À CONSTITUIÇÃO DE UNIÃO ESTÁVEL APLICAÇÃ̃O.IMPEDIMENTO.

1. A jurisprudência desta Corte prestigia o entendimento de que a existência de impedimento para o matrimônio, por parte de um dos componentes do casal, embaraça a constituição da união estável.

2. Agravo regimental improvido ${ }^{99}$

\footnotetext{
97 TRF4, AP/RE 2000.72.04.000915-0, Quinta Turma, Relator: Luiz Antonio Bonat, D.E. $15 / 09 / 2008$.

${ }^{98}$ REsp 1.104.316/RS, Rel. Min. MARIA THEREZA DE ASSIS MOURA, 6a Turma, DJe $18 / 5 / 2009$.
} 
Não obstante, o egrégio Tribunal já decidiu em favor da partilha de pensão entre a viúva e a concubina:

RECURSO ESPECIAL. PENSÃO PREVIDENCIÁRIA. PARTILHA DA PENSÃO ENTRE A VIÚVA E A CONCUBINA. COEXISTÊNCIA DE VÍNCULO CONJUGAL E A NÃO SEPARAÇÃO DE FATO DA ESPOSA. CONCUBINATO IMPURO DE LONGA DURAÇÃO.

"Circunstâncias especiais reconhecidas em juízo". Possibilidade de geração de direitos e obrigações, máxime, no plano da assistência social. Acórdão recorrido não deliberou à luz dos preceitos legais invocados.

Recurso especial não conhecido. ${ }^{100}$

$$
* * *
$$

CIVIL E PROCESSUAL. SEGURO DE VIDA REALIZADO EM FAVOR DE CONCUBINA. HOMEM CASADO. SITUAÇÃO PECULIAR, DE COEXISTÊNCIA DURADOURA DO DE CUJUS COM DUAS FAMÍLIAS E PROLE CONCOMITANTE ADVINDA DE AMBAS AS RELAÇÕES. INDICAÇÃO DA CONCUBINA COMO BENEFICIÁRIA DO BENEFÍCIO. FRACIONAMENTO. CC, ARTS. $1.474, \quad 1.177$ E 248, IV. PROCURAÇÃO. RECONHECIMENTO DE FIRMA. FALTA SUPRÍVEL PELA RATIFICAÇÃO ULTERIOR DOS PODERES.

I. Não acarreta a nulidade dos atos processuais a falta de reconhecimento de firma na procuração outorgada ao advogado, se a sucessão dos atos praticados ao longo do processo confirmam a existência do mandato.

II. Inobstante a regra protetora da família, consubstanciada nos arts. 1.474, 1.177 e 248, IV, da lei substantiva civil, impedindo a concubina de ser instituída como beneficiária de seguro de vida, porque casado o de cujus, a particular situação dos autos, que demonstra espécie de "bigamia", em que o extinto mantinha-se ligado à família legítima e concubinária, tendo prole concomitante com ambas, demanda solução isonômica, atendendo-se à melhor aplicação do Direito.

III. Recurso conhecido e provido em parte, para determinar o fracionamento, por igual, da indenização securitária. ${ }^{101}$

\footnotetext{
${ }^{99}$ AgRg no REsp 1016574/SC, Rel. Ministro JORGE MUSSI, QUINTA TURMA, julgado em 03/03/2009, DJe 30/03/2009.

${ }^{100}$ REsp 742685/RJ, Rel. Ministro JOSÉ ARNALDO DA FONSECA, QUINTA TURMA, julgado em 04/08/2005, DJ 05/09/2005, p. 484.
} 


\begin{abstract}
$* * *$
SERVIDOR PÚBLICO - FALECIMENTO - ESPOSA CONCUBINA -PENSÃO - DIREITO. Comprovada a existência de concubinato, inclusive com reconhecimento de paternidade por escritura pública, devida é a pensão por morte à concubina, que passa a concorrer com a esposa legítima. ${ }^{102}$
\end{abstract}

$* * *$

PENSÃO - ESPOSA E CONCUBINA - DIVISÃO EQUANIME. Agiu bem a autoridade administrativa ao dividir a pensão vitalícia por morte de servidor que em vida manteve concomitantemente duas famílias, entre a esposa legítima e a concubina. Inexiste direito líquido e certo da esposa à exclusividade do recebimento da pensão, se provado está que a concubina vivia sob a dependência econômica do de cujus. Ato administrativo que se

manifesta sem qualquer vício ou ilegalidade. Ordem denegada. ${ }^{103}$

No julgado in verbis, o Ministro José Arnaldo da Fonseca, relator do

REsp $n^{\circ} 742.685 / R J$ aduz, em trecho retirado de seu voto o seguinte:

Ante uma situação de fato dessa ordem, que perdurou por 3 (três) décadas, de que se extrai o reconhecimento de efetiva affectio societatis, poderia o magistrado prostrar-se inerte, indiferente, apegado ao hermetismo dos textos legais, deslembrado do princípio de que, na aplicação da lei, há de se atender aos fins sociais?

É claro que não, máxime em se tratando de benefício meramente assistencial sem envolver direito de herança. ${ }^{104}$

Da mesma forma, no julgado transcrito abaixo, o Ministro Aldir Passarinho, relator do REsp $\mathrm{n}^{\mathbf{0}}$ 100.888/BA explicita, no excerto de seu voto:

101 REsp 100888/BA, Rel. Ministro ALDIR PASSARINHO JUNIOR, QUARTA TURMA, julgado em 14/12/2000, DJ 12/03/2001, p. 144.

${ }_{102}$ TRF - 1a Região - AP.Civ. 1997.01.00.0575528/AM - Rel Juiz Lindoval Marques de Brito publ. em 31.05.1999.

${ }^{103}$ TJ-DF -MS 6648/96 - Acórdão COAD 84999 -Rel. Dês. Pedro de Farias - Publ. em 19.08.1998.

${ }^{104}$ REsp 742685/RJ, Rel. Ministro JOSÉ ARNALDO DA FONSECA, QUINTA TURMA, julgado em 04/08/2005, DJ 05/09/2005, p. 484. 
Na realidade, a situação era de quase uma bigamia, no sentido leigo da palavra. Impossível, assim, tanto ignorar as normas legais acima reproduzidas, fortes na proteção dos direitos da esposa, como também desconhecer-se, em face da situação específica dos autos, a relação concubinária estável, geradora de prole comum, que merece algum amparo, dentro da compreensão mais atual sobre a matéria, inclusive, agora, em face do disposto no art. 226, parágrafo 3o, da Constituição de 1988. ${ }^{105}$

Desse modo, sendo o regime da Previdência Social regido de forma autônoma da do Código Civil, é possível, apesar do não reconhecimento das uniões paralelas pelos Tribunais brasileiros, seja concedido o benefício da Previdência Social às concubinas, sendo este rateado com a esposa do de cujus. Contudo, esse entendimento, embora não é unânime, já é uma realidade.

\section{CONCLUSÃO}

O tema das famílias simultâneas é questão sensível e bastante controversa tanto na doutrina quanto na jurisprudência pátria. Tal problemática se dá ante os valores monogâmicos majoritários da sociedade ocidental e, portanto, brasileira, somados aos valores histórico-sociais, morais e religiosos da cultura brasileira.

É certo, destarte, que, apesar de moralmente condenável, o paralelismo familiar sempre existiu em nossa sociedade e continua existindo. Tais uniões existem e tem a forma de família, embora não sejam reconhecidas como tal. São uniões marginalizadas, invisíveis aos olhos da lei.

Devido à essa invisibilidade, cabe ao Poder Judiciário, ao analisar a temática da simultâneidade familiar casuísticamente, o dever de reconhecêlas ou não dentro do âmbito do direito de família, como entidade familiar.

\footnotetext{
${ }^{105}$ REsp 100888/BA, Rel. Ministro ALDIR PASSARINHO JUNIOR, QUARTA TURMA, julgado em 14/12/2000, DJ 12/03/2001, p. 144.
} 
É essa a discussão travada no presente trabalho monográfico, através de uma análise doutrinária e jurisprudêncial dos diversos Tribunais brasileiros. No decorrer do trabalho, observou-se que apesar da grande evolução do direito de família ao longo dos anos, há, ainda, uma certa dificuldade em romper com as amarras patriarcais e patrimoniais, heranças essas de um Brasil Colonial.

Neste sentido, por um lado, a doutrina majoritária, bem como a jurisprudência domintante em grande parte dos Estados brasileiros são no sentido do não reconhecimento das uniões simultâneas como entidades familiares. Conforme essa corrente, deve prevalecer o princípio monogâmico como base da estrutura familiar brasileira, não sendo admissível que se reconheça como família, aquela que afronta esse princípio basilar.

Assim, a jurisprudência, ao julgar casos de simultâneidade familiar, afasta a possibilidade de reconhecê-las no âmbito do direito de família, aplicando a Súmula 380, STF, a fim de evitar o enriquecimento ilícito, tratando os relacionamento afetivos como uma mera sociedade de fato. É o Poder Judiciário fechando os olhos para uma realidade gritante, cometendo assim uma série de injustiças e afrontando princípios fundamentais consagrados na nossa Constituição Federal, como a dignidade da pessoa humana.

Por outro lado, vem ganhando cada vez mais força a corrente minoritária, composta, doutrinariamente, pela ilustríssima Maria Berenice Dias, entreoutros, cujos julgados advém majoritariamente dos Tribunais do Rio Grande do Sul e de Minas Gerais. Essa corrente tem como fundamento o afeto como base das relações familiares contemporâneas. Desse modo, acreditam que o princípio eudemonista prevalece sobre o princípio monogâmico, este cada vez mais ultrapassado.

Neste diaspasão, a família contemporânea é fundada no amor, no afeto entre as partes. A família matrimonializada não se sobrepõe à 
nenhuma outra forma de família, tendo sido a união estável reconhecida e equiparada ao casamento.

Dessa forma, há de se reconhecer uniões simultâneas como entidades familiares, se houver caracterizada a presença do elemento basilar afetivo entre os intergrantes da relação amorosa. Entendendo desta forma, já há julgados reconhecendo as uniões simultâneas como entidade familiar, deferindo a divisão do patrimônio entre a esposa e a companheira, em caso de extinção da sociedade conjugal por morte.

Nesta linha, apesar de ainda minoritária, na seara do direito previdenciário, há julgados concedendo o benefício da Previdência Social às concubinas, sendo este rateado com a esposa do de cujus. Isso porque, o regime da Previdência Social é regido de forma autônoma da do Código Civil, sendo possível conceder o benefício apesar do não reconhecimento das uniões paralelas pelos Tribunais brasileiros.

Com efeito, essa é uma discussão bastante relevante, haja vista a grande quantidade de uniões paralelas formadas simultaneamente à margem de qualquer proteção estatal. Deve-se afastar o preconceito em prol da justiça, a fim de garantir direitos e deveres decorrentes da formação de uma entidade familiar, independente de haver outra preexistente à essa. É essa a evolução do direito de família que se almeja, cujo elemento norteador é o afeto.

\section{BIBLIOGRAFIA}

ALBUQUERQUE FILHO, Carlos Cavalcanti. Famílias Simultâneas e concubinato adulterino. In: PEREIRA, Rodrigo da Cunha (Coord.). Família e cidadania, o novo $C C B$ e a vacatio legis. Belo Horizonte: IBDFAM, Anais do III Congresso Brasileiro de Direito de Família, 2002.

Aristóteles, Ética a Nicômaco 1.12.8. 
AZEVEDO, Álvaro Villaça. Estatuto da Família de Fato. $2^{\mathrm{a}}$ edição. São Paulo: Atlas, 2002.

CHAVES, Mariana. Famílias Paralelas. IBDFAM, 2009. Disponível em: $<$ https://www.ibdfam.org.br/artigos/autor/Marianna\%20Chaves $>$ Acesso em 24 mar. 2014.

COMEL, Denise Damo. Do Poder Familiar. São Paulo: Revista dos Tribunais, 2003.

DAL COL, Helder Martinez. A união estável perante o novo código Civil. IN: CAHALI, Yussef Said; CAHALI, Francisco José (Coord.). Edições especias, 100 anos, Doutrinas Essenciais: Família e Sucessões, vol. II, Entidades Familiares. Revista dos Tribunais, 2011.

DIAS, Adahyl Lourenço. A concubina e o Direito Brasileiro. $2^{\mathrm{a}}$ edição. São Paulo: Saraiva, 1975.

DIAS, Maria Berenice. A união estável. Disponível em: $<$ http://www.mariaberenice.com.br/uploads/3 _a_uni\%E3o_est\%E1vel.pdf> Acesso em 11 mar. 2014.

DIAS, Maria Berenice. Adultério, bigamia e união estável: realidade e responsabilidade. em: $<$ http://www.mariaberenice.com.br/uploads/4_adult\%E9rio\%2C_bigamia _e_uni\%E3o_est\%E1vel_-_realidade_e_responsabilidade.pdf> Acesso em 11 mar. 2014.

DIAS, Maria Berenice. Manual de Direito das Famílias. $8^{a}$ edição. São Paulo: Revista dos Tribunais, 2011. 
DIAS, Maria Berenice. Sociedade de afeto. Disponível em: 〈http://www.mariaberenice.com.br/uploads/1___sociedade_de_afeto.pdf > Acesso em 11 mar. 2014.

DIAS, Maria Berenice. União Homossexual: aspectos jurídicos. Disponível em: <http://www.gontijofamilia.adv.br/2008/artigos_pdf/Maria berenice/Uniaohomo.pdf> Acesso em 27 mar. 2014.

FARIAS, Cristiano Chaves de; ROSENVALD, Nelson. Curso de Direito Civil: Famílias. 4º edição. Bahia: JusPodivam, 2012.

GOECKS, Renata Miranda; OLTRAMARI, Vitor Hugo. A possibilidade do reconhecimento da união estável putativa e paralela como entidade familiar frente aos princípios constitucionais aplicáveis. In: MADALENO, Rolf; MILHORANZA, Mariângela Guerreiro (Coord.). Atualidades do Direito de Família e Sucessões. Sapucaia do Sul: Notadez, 2008.

LÔBO, Paulo Luiz Neto. A Repersonalização das Relações de Família. In: DEL'OLMO, Florisbal de Souza; ARAÚJO, Luís Ivani de Amorim (coords.). Direito de Família Contemporâneo e os novos direitos. Rio de Janeiro: Forense, 2006.

LÔBO, Paulo Luiz Netto. Entidades familiares constitucionalizadas: para além do numerus clausus. Anais do III Congresso Brasileiro de Direito de Família. Belo Horizonte, 2002.

LÔBO, Paulo. Direito Civil: Famílias. São Paulo: Saraiva, 2008.

LOUZADA, Ana Maria Gonçalves. Evolução do conceito de família. 2012. Disponível em: $<$ http://www.amagis.org.br/index.php?option=com_content\&view=article $\&$ 
$\underline{\mathrm{id}=191 \% 3 \text { Aevolucao-do-conceito-de-familia-juiza-ana-maria-goncalves- }}$ louzada\&catid=11\&Itemid=30> Acesso em 20 mar. 2014.

MADALENO, Rolf. Curso de Direito de Família. $4^{\mathrm{a}}$ edição. Rio de janeiro: Forense, 2011.

MADALENO, Rolf. A União (Ins)Estável (Relações Paralelas). Disponível em: <http://www.flaviotartuce.adv.br> Acesso em 20 abr. 2014.

MOTTA, Carlos Dias. Direito matrimonial e seus princípios jurídicos. São Paulo: Revista dos Tribunais, 2006.

OLIVEIRA, José Lamartine Correa de; MUNIZ, Francisco José Ferreira. Curso de Direito de Família. 4a edição. Curitiba: Juruá, 2002.

PEREIRA, Rodrigo da Cunha. Concubinato e União Estável. $7^{\mathrm{a}}$ edição. Belo Horizonte: Del Rey, 2004.

PEREIRA, Rodrigo da Cunha. Disponível em: $<$ http://www.rodrigodacunha.adv.br/instituicao-da-poligamia/> Acesso em 26 abr. 2014.

PEREIRA, Rodrigo da Cunha. Princípios Fundamentais Norteadores do Direito de Família. Belo Horizonte: Del Rey, 2006.

PEREIRA, Sérgio Gischkow. Estudos de Direito de Família. $1^{\text {a }}$ edição. Porto Alegre: Livraria do Advogado Editora, 2004.

PIANOVSKI, Carlos Eduardo. Famílias Simultâneas e Monogamia. IN: PEREIRA, Rodrigo da Cunha (Coord.). Família e Dignidade Humana: Anais do V Congresso Brasileiro de Direito de Família. São Paulo: IBDFAM, 2006. 
PORTO, Mário Moacyr. O concubinato e as súmulas $n^{\circ} 35$ e 380 do STF. Porto Alegre: AJUIRS, Revista da Associação dos Juízes do RGS, 1984.

RIZZARDO, Arnaldo. Direito de Família. $2^{\mathrm{a}}$ edição. Editora Forense, 2004.

SANTOS, Regina Beatriz Tavares da Silva Papa dos. Responsabilidade Civil dos Cônjuges. IN: A Família na Travessia do Milênio: Anais do II Congresso Brasileiro de Direito de Família. IBDFAM. Belo Horizonte: Del Rey, 2000.

TARTUCE, Flávio. Manual do Direito Civil: Volume Único. Rio de Janeiro: Forense, 2011.

TEPEDINO, Gustavo. Temas de Direito Civil. Rio de Janeiro: Renovar, 2004.

VELOSO, Zeno. Homossexualidade e direito. Belém: Jornal O Liberal, 1999.

VELOSO, Zeno; AZEVEDO, Álvaro Villaça (Coord.) Código Civil Comentado. Vol. XVII. São Paulo: Atlas, 2003.

VIANA, Marco Aurélio S.. Da União Estável. São Paulo: Saraiva, 1999.

Apelação Cível 1.0017.05.016882-6/003, Relator(a): Des.(a) Maria Elza , $5^{\text {a }}$ CÂMARA CÍVEL, julgamento em 20/11/2008, publicação da súmula em $10 / 12 / 2008$ 
Apelação Cível 1.0024.07.690802-9/001, Relator(a): Des.(a) Maria Elza , $5^{\text {a }}$ CÂMARA CÍVEL, julgamento em 18/12/2008, publicação da súmula em 21/01/2009.

Apelação no 0006502-19.2011.8.19.0210; Des. Mario robert Mannheimer; Julgamento: 23/05/2013; Decima Sexta Camara Civel.

STF, RE 590779, Relator(a): Min. Marco Aurélio, Primeira Turma, julgado em 10/02/2009.

STJ, AgRg no REsp 1016574/SC, Rel. Ministro Jorge Mussi, QuintaTurma, Santa Catarina, julgado em 03/03/2009, DJe 30/03/2009.

STJ, Informativo $\mathrm{n}^{\mathrm{o}}$ 0435; Período: 17 a 21 de maio de 2010; Terceira Turma.

STJ, Informativo $n^{\circ}$ 0441; Período: 28 de junho a 6 de agosto de 2010; Terceira Turma.

STJ, REsp 1.104.316/RS, Rel. Min. Maria Thereza De Assis Moura, 6 ${ }^{\mathrm{a}}$ Turma, DJe 18/5/2009.

STJ, REsp 100888/BA, Rel. Ministro Aldir Passarinho Junior, Quarta Turma, julgado em 14/12/2000, DJ 12/03/2001, p. 144.

STJ, REsp 742685/RJ, Rel. Ministro José Arnaldo Da Fonseca, Quinta Turma, julgado em 04/08/2005, DJ 05/09/2005, p. 484.

STJ, REsp 742685/RJ, Rel. Ministro José Arnaldo Da Fonseca, Quinta Turma, julgado em 04/08/2005, DJ 05/09/2005, p. 484.

STJ, REsp 100888/BA, Rel. Ministro Aldir Passarinho Junior, Quarta Turma, julgado em 14/12/2000, DJ 12/03/2001, p. 144. 
STJ, REsp 931155/RS, Rel. Ministra Nancy Andrighi, Terceira Turma, julgado em 07/08/2007, DJ 20/08/2007, p. 281.

STJ, Resp n 912.926 - RS, Rel Ministro Luis Felipe Salomão, 4ª turma, pub. 07/06/2011.

STJ, Resp. n .157.273 - RN, $3^{\text {a }}$ turma, Rel Min. Nancy Andrighi, Publ. em 07 jun. 2010.

TJ/DF, MS 6648/96, Acórdão COAD 84999, Rel. Dês. Pedro de Farias, Publ. em 19.08.1998.

TJRS, ApC N. ${ }^{\circ} 70027512763,8^{\text {a }}$ Câmara Cível, Rel. Rui Portanova, Rio Grande do Sul, Julg. em 14 maio 2009.

TJRS, Apelação Cível Nº 70001494236, Sétima Câmara Cível, Tribunal de Justiça do RS, Relator: Sérgio Fernando de Vasconcellos Chaves, Julgado em 20/12/2000.

TJRS, Apelação Cível Nº 70010787398, Sétima Câmara Cível, Tribunal de Justiça do RS, Relator: Maria Berenice Dias, Julgado em 27/04/2005.

TJRS, Apelação Cível No 70011258605, Oitava Câmara Cível, Tribunal de Justiça do RS, Relator: Rui Portanova, Julgado em 25/08/2005.

TJRS, Apelação Cível Nº 70012696068, Oitava Câmara Cível, Tribunal de Justiça do RS, Relator: José Ataídes Siqueira Trindade, Julgado em 06/10/2005.

TJRS, Apelação Cível Nº 70016516932, Sétima Câmara Cível, Tribunal de Justiça do RS, Relator: Maria Berenice Dias, Julgado em 08/11/2006. 
TJRS, Apelação Cível No 70019387455, Oitava Câmara Cível, Tribunal de Justiça do RS, Relator: Luiz Ari Azambuja Ramos, Julgado em 24/05/2007; Publicação: Diário da Justiça do dia 21/06/2007.

TJRS, Apelação Cível No 70022775605, Oitava Câmara Cível, Tribunal de Justiça do RS, Relator: Rui Portanova, Julgado em 07/08/2008; Publicação: Diário da Justiça do dia 18/08/2008.

TJRS, Apelação Cível no 70039284542, Oitava Câmara Cível, Rel. Rui Portanova, Julg. em 23 dez. 2010.

TJRS, Embargos Infringentes nº 70020816831, Quarto Grupo de Câmaras Cíveis, Tribunal de Justiça do RS, Relator: Ricardo Raupp Ruschel, Julgado em 14/09/2007; Publicação: Diário da Justiça do dia 19/10/2007.

TJSP, AgRg no Ag 746.042/SP, Quarta Turma, Rel. Min. Fernando Gonçalves, São Paulo, DJ de 17 set. 2007.

TRF - $1^{\text {a }}$ Região - AP.Civ. 1997.01.00.0575528/AM - Rel. Juiz Lindoval Marques de Brito. Publ. em 31 maio 1999.

TRF - 4 ${ }^{a}$ Região, AP/RE 2000.72.04.000915-0, Quinta Turma, Rel. Luiz Antonio Bonat, D.E. 15 set. 2008. 


\section{ANEXO II}

A Monografia deve ser entregue até o dia 15 de maio de 2014.

A presente Monografia, apresentada pela aluna IONÁ CYTRYNBAUM $\underline{\text { SPATZ, }}$ poderá ser submetida à exposição e defesa perante a Banca Examinadora designada pelo Departamento de Direito da PUC-Rio.

Rio de Janeiro, 15 de maio de 2014.

\section{BRUNO VAZ}

Nome do (a) professor (a) orientador (a)

Assinatura do (a) professor (a) orientador (a)

O (A) autor (a) declara para todos os fins de Direito ser este um trabalho inédito de sua autoria e autoriza o Departamento de Direito da PUC-Rio a divulgá-lo, no todo ou em parte, resguardados os direitos autorais conforme legislação vigente.

Rio de Janeiro, 15 de maio de 2014.

Assinatura do (a) aluno (a) 